\title{
Risk Assessment for Karst Hazards at a Facility in Saudi Arabia-A Case Study
}

\author{
Bassim A. Nawaz' ${ }^{1}$ Emmanouil Spyropoulos' ${ }^{1}$ Adly Kh. Al-Saafin² \\ ${ }^{1}$ Saudi Aramco, Dhahran, KSA \\ ${ }^{2}$ Gulf Consult, Al-Khobar, KSA \\ Email: bassim.nawaz@aramco.com,emmanouil.spyropoulos@aramco.com, adly@gulfconsult.com
}

How to cite this paper: Nawaz, B. A., Spyropoulos, E., \& Al-Saafin, A. Kh. (2020). Risk Assessment for Karst Hazards at a Facility in Saudi Arabia-A Case Study. Journal of Geoscience and Environment Protection, 8, 277-312.

https://doi.org/10.4236/gep.2020.85018

Received: April 4, 2020

Accepted: May 26, 2020

Published: May 29, 2020

Copyright $\odot 2020$ by author(s) and Scientific Research Publishing Inc. This work is licensed under the Creative Commons Attribution International License (CC BY 4.0).

http://creativecommons.org/licenses/by/4.0/

(c) (i) Open Access

\begin{abstract}
The boom in industrial and infrastructure construction in Saudi Arabia requires in-depth knowledge of the underground conditions to build a sustainable project. This paper gave a practical example of the challenges facing an existing facility built on a karstic limestone formation in 1970's. Multiple geophysical techniques such as Microgravity, Electrical Resistivity Imaging, Vertical Seismic Velocity Profiling, Cross Hole Seismic Tomography, Ground Penetration Radar, Multi-Channel Analysis of Surface Waves, as well as boreholes and down-hole video imagery, were deployed through the journey of assessing the karst associated hazards of potential sinkholes or general subsidence. This paper described the karst processes, site geology, geophysical and geotechnical exploration program, and characterizes the subsurface karst conditions at the eastern province of Kingdom of Saudi Arabia. Results and findings of preliminary, geotechnical and geophysical investigations have been utilized to identify the major factors influencing the karst formation. Analyses and integration of obtained results to estimate the type and magnitude of risk affected the major components of industrial facility at the project site using well-known statistical approach were presented in this paper. Consequently number of remedial measures implemented to combating the experienced and expected karst hazards at the studied industrial facility placed in karstified landform are given. A model for using integrated geophysical and geotechnical techniques to assess karst-related risks to a facility was further explored herein.
\end{abstract}

\section{Keywords}

Risk Assessment, Cavities, Karst, Subsidence, Sinkholes, Karst Hazard, Remedial and Preventive Measures 


\section{Introduction}

Karst terrain is generic term that describes areas which mimic the landforms found on the Karst Plateau in Slovenia, Cvijić, 1893. The term has also come to mean any features that are the result of dissolution of the bedrock, which might be carbonate, but also includes evaporates such as gypsum or halite. Although gypsum and halite can weather and erode very quickly under specific kinds of conditions, carbonate karst systems are relatively slow to develop.

The rate of dissolution in carbonate rocks is strongly dependent on climate, saturation, the amount of carbonate in the system to buffer groundwater with low $\mathrm{pH}$, the type of materials (carbonate or not) up-gradient of the site, the rate in which groundwater flows through the rock, amount of magnesium in the rock, $\mathrm{pH}$ of the groundwater, etc. (Dreybrodt \& Eisenlohr, 2000). Therefore, the actual rate of dissolution is difficult to evaluate precisely. However, typical rates may vary from less than $1 \mathrm{mg} / \mathrm{cm}^{2}$ per year to about $1000 \mathrm{mg} / \mathrm{cm}^{2}$ per year (White, 1988), which indicates that voids and caverns may take thousands of years or more to develop. Sinkholes and general subsidence are therefore the result of instability within the existing subsurface system. Karst is frequently characterized by different features such as caves, dolines (sinkholes), shafts, poljes, caverns, underground river systems, denuded rocky hills, karst plains, and collapses (Milanovic, 2004).

The primary hazard to engineered structures in karst terrain is loss of foundation support, which commonly occurs in two forms: sinkholes and general subsidence. The most dramatic type occurs in the form of sinkholes that leave open holes in the ground surface and can compromise the vertical and lateral support of structures, depending on the size and location of the sinkhole relative to the structure and the foundation system used. Sinkholes occur when overburden (soil and/or rock) migrates downward into the underlying bedrock.

Loss of foundation support may also occur from general subsidence over buried karst features. Subsidence generally happens via two modes: 1) material ravels into the underlying bedrock which loosens the overburden soil causing it to sag; and 2) consolidation of soft under-consolidated soil at the bedrock surface due to the self-weight and/or surcharge loads from structures placed on the soil.

In the last three decades, number of research studies for karst studies for karst matters within different applications have been undertaken. During this period, number of geotechnical investigation projects have been performed. It is noticed that severe misunderstanding and misleading the interaction of karst geology, geomorphology, karst hydrogeology karst formation, karst classification in the geotechnical engineering applications. Therefore, we intended to prepare this paper to demonstrate a case study for karst hazard assessment to be present a directional and operational approach for identification and evaluation the susceptibility of karst futures formation (e.g. sinkholes, voids, underground cavities and collapsing) that may occur and endanger the industrial and residential facilities placed on karst landform, and then to provide the most adequate mitigation control measures to combating the expected/experienced karst hazard in a sys- 
tematical approach.

\section{Background}

Number of authors reported that the presence of natural karst features (e.g. cavities, caves, caverns, voids, karst, and sinkhole) in subsurface carbonates and evaporites causes severe problems for civil engineering and environmental management (Sum et al., 1996). It is noticed that the karstification process will continue till reaches a critical stage, where roof of the space will no longer support the weight of the overburden and other foundations. This will result in the development of sinkholes, which have adverse impacts and catastrophic effects on both shallow and deep foundations. The presence of such cavernous features leads to restrictions in land utilization and causes variable geotechnical hazards like ground surface subsidence, collapsing of surface structures, cracks and fissures in the surface buildings (Fischer \& Canace, 1989).

\subsection{Karst Classification for Geotechnical Engineering Purposes}

Recently, it is realized that Karst frequently presents "difficult ground conditions" to engineers, and is often inadequately understood by those only familiar with insoluble rock (Geologists) or foundation design (Geotechnical Engineers). Therefore, number of scientists have developed and improved an adequate practical karst classification for engineering purposes based on morphology, formation, process, location, dimension and complexity of karst features; and its impacts on foundation (Fookes \& Hawkins,1988; Ford \& Williams, 1989 and Waltham \& Fookes, 2003) to put the key points how to design in Karst terrain as follows:. Karst ground conditions for engineering applications are divided into a progressive series of five classes ( $\mathrm{kI}$ to $\mathrm{kV}$ ) based on typical morphological assemblages. Additionally, the essential parameters describing each class for geotechnical applications (e.g. location, associated sinkhole and caves, fissures, rockhead, recommended investigation and type of foundation) are summarized and presented in (Figure 1) Additionally, a special classification of karst sinkholes for engineering purposes was developed by Waltham \& Fookes, 2003 based on the mechanisms of the ground failure and the nature of the material which fails and subsides (Figure 2).

International experiences considered understanding the process of karst formation is a key for engineering design for structures placed on karstic terrain. Therefore, both karst classification schemes for engineering practice have been utilized fully in number of projects and showed a significant role in understanding the type, characteristics, karst formation process, mode and degree of karst hazard that could trigger the structures and then applied the most adequate recommendations for prevention and remediation the expected karst hazard encountered at the project sites (Bennett, 1997, and Fookes \& Hawkins, 1988; Xeidaki et al., 2004; Reith et al. 1999; Kannan, 1999; Siegel et al., 1999 and Villard et al., 2000). 


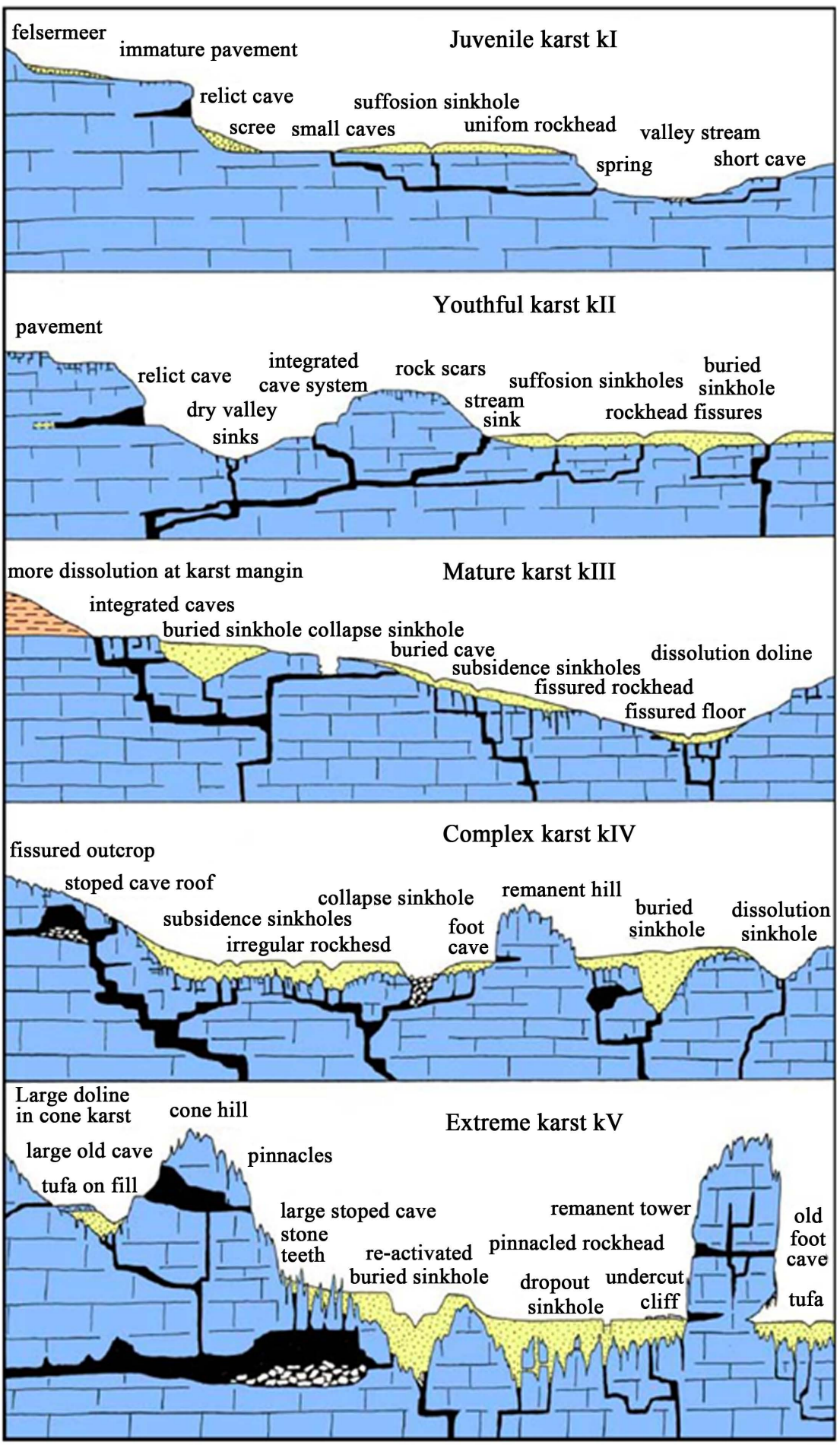

Figure 1. An engineering classification of Karst for engineering applications (after Waltham \& Fookes, 2003).

So that, engineering classification schemes of karst features are considered as essential and good practice in ground engineering and will offer guidelines towards more efficient Karst hazard assessment and Geotechnical Investigation activities. 


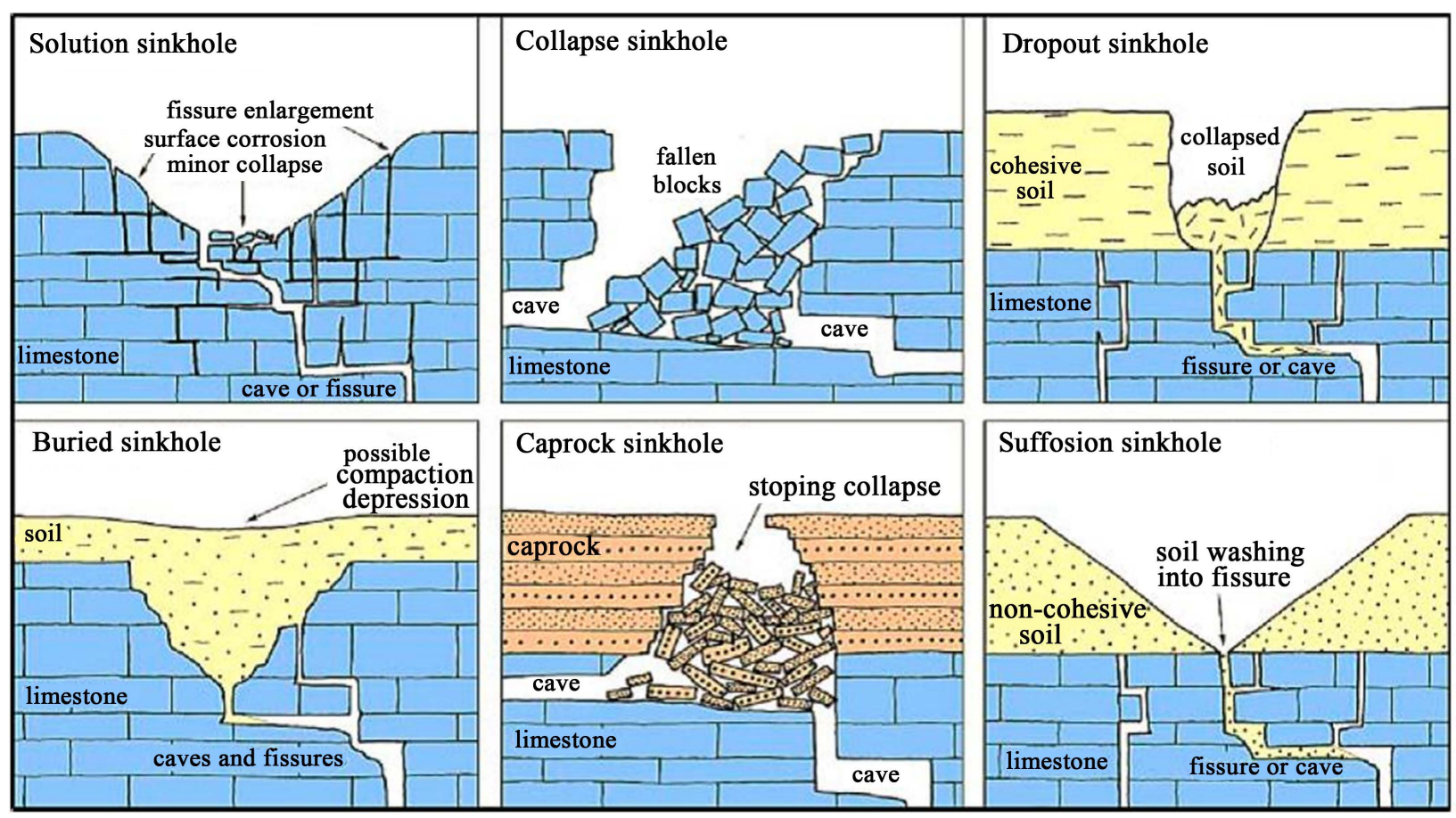

Figure 2. A classification of Karst sinkholes for engineering applications, after Waltham \& Fookes, 2003.

\subsection{Karstification Phenomenon in the Kingdom of Saudi Arabia}

Karstification phenomenon in the Kingdom of Saudi Arabia are distributed in the carbonate and evaporite formations dominated in the Phanerozoic zone have been studied by different Authors and Organizations (Peters et al., 1990; Pint \& Bjurström, 2000, Pint, 2003; Youssef et al., 2016 and Al-Saafin, 2007, RI-KFUMP, 1984-1999 and SGS, 2000-2016). Many karst features (e.g. sinkholes, depressions, underground cavities, shafts, cavernous and voids) discovered in the carbonate and evaporite rocks within the Phanerozoic karst zone distributed in the Northern, Eastern Provinces and Central Area of Saudi Arabia are shown Figure 3.

Comprehensive research studies conducted by RI-KFUPM (1984-1999), Dhahran and SGS, Jeddah in the eastern parts of Saudi Arabia for different purposes reported that karstification landforms over the Eastern and Northern parts of Saudi Arabia are distributed in the carbonate and evaporite formations of Umm Er Radhuma, Rus, Dammam; Dam Formations, and Salt Dome. Karst features at these formations have been developed as a result of the chemical leaching of the carbonate and evaporite formations by percolating water along the predominant jointing and fracturing systems.

Different types of karst features (Sinkholes, depressions, stream, underground cavities and voids) with different sizes and at different depths have discovered in Al-Hassah, Dhahran, Al-Khobar, Dammam, Ma'aglah, Shawiah, Hafr Al Batin, and Arra'r cities in the Eastern and northern provinces of Saudi Arabia (Figure 3) and tentatively classified for engineering purposes (Waltham \& Fookes, 2003) as Immature Karsts (Classes kI \& kII) and Mature Karst (Classes kIII - kV). 


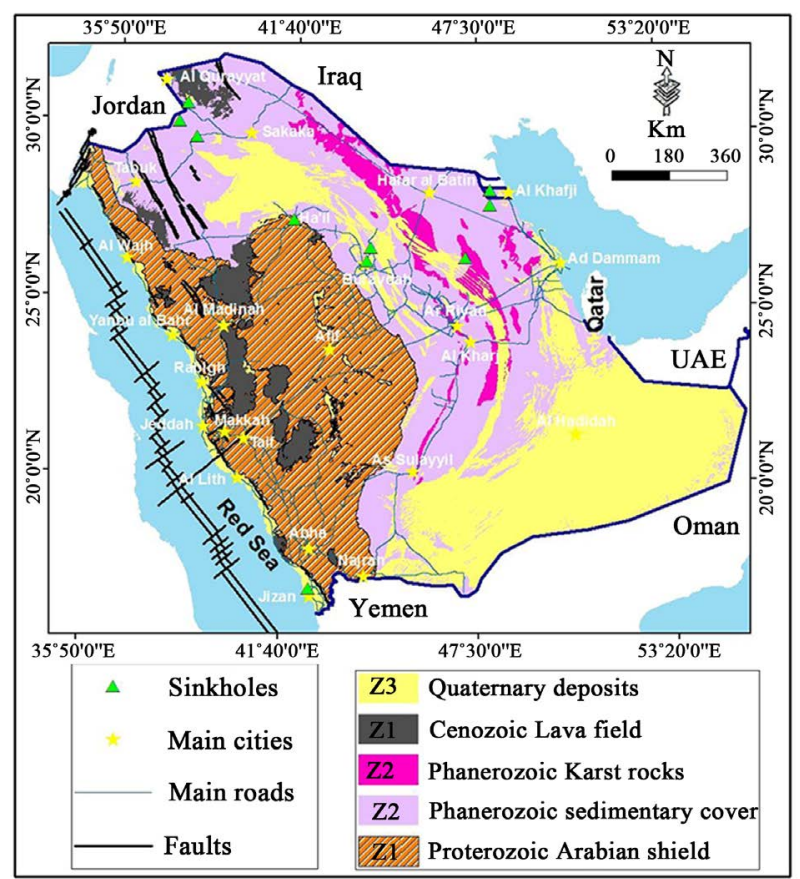

Figure 3. Generalized Geological Mp showing the karstic features (sinkholes and fissures) distributed in the Karst Phanerozoic Rocks zone distributed in Saudi Arabia. Karst feature at the study site (Blue Triangle) (modified after Youssef et al., 2016).

In this context, it is worth mentioning that in the last four decades, a great interest have given by different authors, institutes and organizations to study the karstification phenomenon in Saudi Arabia for many purposes such as formation of karst features, detection and impacts of karst on engineering and environmental projects, replenishment of groundwater and mitigation of karst hazards to safe and secure the structures placed on karst terrains. For instance, Davies \& Lord (1981) investigated the effect of cavities in the Ad Dammam and Rus formations (limestone) in the city of Al Khobar. Jado and Johnson (1984), reported two large solution cavities in the Dammam dome. Vaslet et al. (1988), investigated a crevasse formed by solution action in Al Kharj area. Al Saafin \& Ramos (1989), examined the geomorphology and groundwater recharge in the karstic terrain of the As Summan Plateau in the Umm Er Radhuma Formation, Ma'aglah area in Saudi Arabia. Zabramawi et al. (2009) conducted Karst study in An Nu'ayriyah area. Sabtan et al. (2013) evaluated the sinkhole hazard at Al Issawiah, south of Qurayat, Jouf Region in the Northern Province of Saudi Arabia. Al-Saafin et al. (2018) and Al-Saafin \& Ramos (2019) examined, detected the underground cavities for geotechnical purposes in Al-Hassah area using Remote Sensing, Geotechnical and Geophysical investigations. Grosch et al. (1987) studied the cavities and mechanically eroded features in the Dammam and Hadrukh formations. Lord, 1981, El-Ruwaih \& Khandker, 1981, Dhowian \& Youssef, 1981 and Touma \& Bellerjeau, 1981 and Al-Sayari \& Zotl, 1978, studied and reported the impact of cavities dominated in Dammam and Rus formations in the city of Al Khobar, Dhahran and Al-Hassah area. 


\section{Study Site}

A sound industrial facility site located in Al-Hassah Region southwest of AlHofuf city with about $7 \mathrm{~km}$ has been selected as a case study to demonstrate the methodology of karst hazard assessment as a part of geotechnical investigation.

The designated study site is located within a fenced compound of about $146,000 \mathrm{~m}^{2}$. It includes water storage and storm water management ponds, a maintenance facility, and several ancillary structures. The facility also includes a control building on the northern side of water pumps, pipe scraper facilities, and several large, lined process storage ponds on the south and eastern sides of the site.

Five of the pumps are located in a line extending east-west, just south of the center of the site. The sixth turbine-driven pump is located near the southern boundary of the site.

Field observations and historical records at the study site reported that there are several "collapse features" were noticed in the vicinity of the study site in Hassah Region, and potentially underlying the site, and there are indications of historical karstic activity in the region. The "collapse features" were observed as enclosed depressions in historical aerial photographs and subsequently confirmed visually on the ground surface and via surveyed topographic plans. The area to the west of the compound where sinkholes have previously developed represents one of these enclosed depressions.

Sinkholes previously developed to the west of the study site in or around 1993 and were backfilled. Additional sinkholes developed in 1997. The last known sinkholes developed as a pair to the west of the site and were observed after large amounts of water $(10,000$ gallons or more) were released to that area in or around 2006 from cleaning the former biocide tanks that were previously located in the southwestern portion of the compound.

The two sinkholes both had openings around 1 meter in diameter and the cavity belled out below the ground surface to a larger unknown diameter. The sinkhole openings also had erosional scars from the water flowing into them and tension cracks developed around the openings. Stakes were driven into the ground to mark the tension crack locations.

The enclosed depression which is the site of sinkholes in vicinity of the study site was initially developed around 1993 and surveyed in 2002.

\section{Method of Study}

With reference to the National, International experience as will our involvements in studying and evolution the karst terrain for engineering purposes (Waltham \& Fookes, 2003) it is intended to carry out this study using a combination methods to accomplish and satisfy the main objective of this study, throughout the following sequential steps: 
1) Preliminary site investigation,

2) Geotechnical Investigation,

3) Geophysical Investigation, and

4) Probabilistic analysis.

Methodology, results and findings of the above mentioned methods designated for this study will be discussed and summarized in the following sections:

\subsection{Preliminary Site Investigation}

A special emphasis has been given to carry out a Preliminary Site Investigations at the study site to build a thorough understanding on the natural setting encompassing the study site and its interrelationship to karstification phenomenon.

Previous geological, geotechnical, hydrogeological reports, geological maps, topographical maps, aerial photos and landsat images pertinent to study site and surrounding area have been collected. Additionally, a reconnaissance site visit has been executed to check the karstification landforms and karst features at the study site and surrounding area.

Results and findings of the preliminary site investigation has been gathered, tabulated, studied, analyzed and interpreted to determine the major parameters that could contribute to karst formation. Short description and discussion of the gathered findings are summarized in the following sections:

\subsubsection{Geomorphological and Topographical Setting}

Topographic map study showed that the study site is located in Al-Hassah Region south west of Al-Hassah City. It is bounded with Jafurah sand seas on the eastern side and Assuman Plateau in the west side, and located on the east side of En Nala anticline axis which extends gently to north south

Generally, the study site and surrounding area is located in a lowland area covered by Aeolian sand dunes and sand sheets that range in thickness up to a couple of meters. Underlying ground surface at the study area consists of sandy soil with carbonate fragments (gravel).

Landsat images, and DEM study along with field observations showed that the study site is located in lowland area surrounded with uplifted cliffs and escarpment. in the north and northwest sides. Elevation at the study sites and surrounding area ranges from $150 \mathrm{~m}$ to $154 \mathrm{~m}$ above sea level (maSL), while elevation of uplifted cliffs and escarpment in the north and north west reaches up to 170 maSL as shown in Figure 4. It is noticed that no pronounced streams occur at the study site because all rainfall over the study site percolate into the subsurface and evaporate.

The study site as a part of Al-Hassah region is located in arid zone, Temperature ranges from $24^{\circ}$ to $42^{\circ}$ but may exceed $50^{\circ}$. The annual rainfall over Al-Hassah region reaches up to $100 \mathrm{~mm}$ per year. Rainy period over the study site is about 18 days per year, some thunderstorms with a maximum rain event reaches up to $52 \mathrm{~m}$ in a 24-hr period, and an average of 6 days per year 


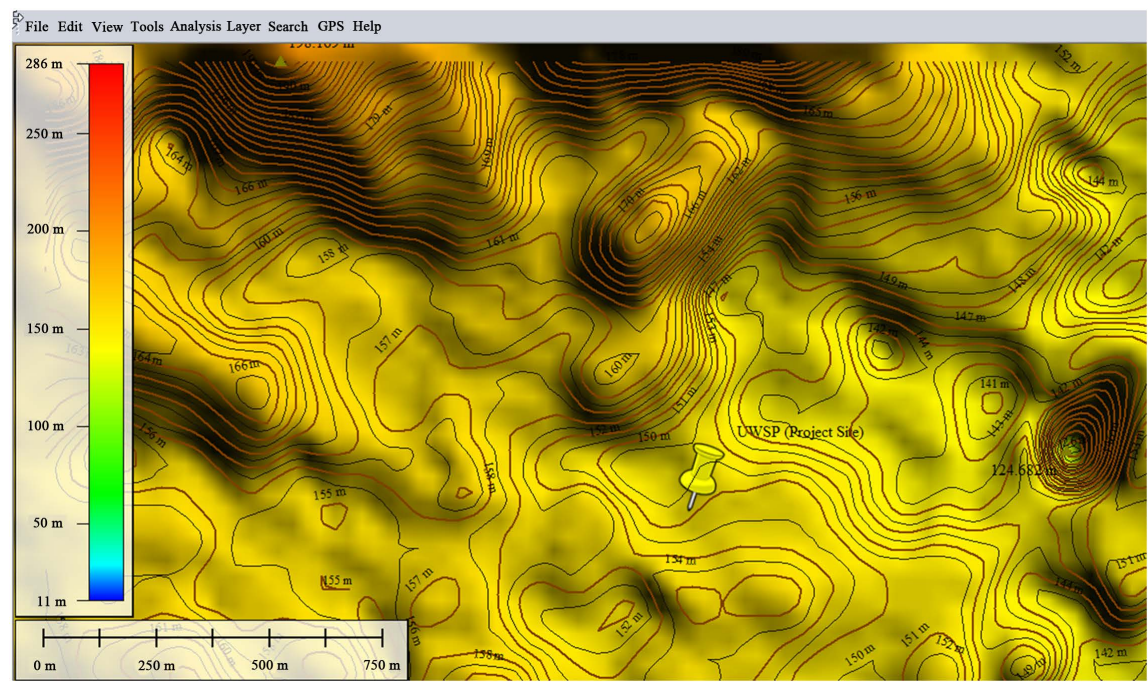

Figure 4. DEM showing the topography at the study site (UWSP) and surrounding area.

\section{(Williams, 1974).}

Additionally, Reconnaissance study, field observation and historical records showed the study site and surrounding area are dominated with pronounced karst features such as subsidence, buried and opened sinkholes, opened shafts and underground cavities.

\subsubsection{Geological Setting}

Geological map of the Arabian Gulf quadrangle (Powers et al., 1966) and a specific geological studies of Hofuf (Hussain et al., 2006) and Shedgum area (Saner et al., 2005) that are in vicinity to the study site depicted that the study site is mapped within the Shedgum Plateau. The Plateau is capped by relatively resistant limestone and raised above the surrounding terrain. Shedgum Plateau as part of En Nala Anticline are slightly inclined at the ground surface and bedding on the eastern side of the anticline dips very slightly to the east and southeast.

Generally, the study site is located at the base of Shedgum plateau that is characterized with the following Lithostratigraphical sequence from youngest to oldest (Figure 5):

1) Hofuf Formation, is comprised of alternating of limestone, marl, sandstone and a thin veneer of highly weathered conglomerate.

2) Dam Formation, consists mainly of limestone, marl interbedded with thin layers of clay and gypsum.

3) Hadrukh Formation is mainly composed of calcareous silty sandstone and sandy marl with some sandy limestone.

4) Dammam Formation consists mainly of limestone, dolomite, marl and chalk with thin layers of gypsiferous shales.

5) Rus Formation mainly comprised primarily dolomitic marl, limestone and gypsum.

6) Um Er Radhuma formation consists of limestone, dolomitic limestone and dolomite. 


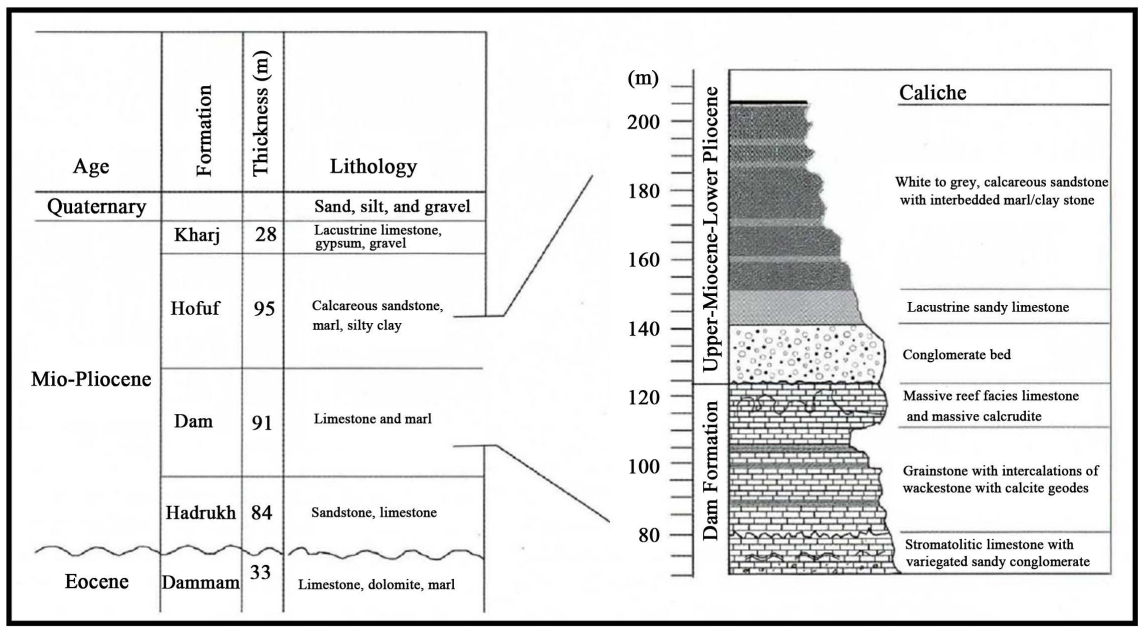

Figure 5. Generalized Lithostratigraphical sequence at Hofuf area (modified by Hussain et al., 2006, after Powers et al., 1966; Al-Sayari \& Zotl, 1978).

\subsubsection{Geological Structures}

Geological Structures as a prime factor controlling karst formation in Shedgum Plateau, As Samman Plateau, Dammam Dome and surrounding area in AlHassah and Ma'aglah region have been studied by many authors for different purposes (Holtz, et al., 1978; Edgell, 1990; Al-Husseini, 2000; Saner et al., 2005 and Hussain et al., 2006).

Results of Research studies carried out by number of authors reported that Al-Hassah region that is hosting the study site and surrounding area in the eastern parts of Saudi Arabia had been affected and triggered by number of major structures such as Ghawar anticline, En Nalah anticline, Abu Jifan and Sahba faulting system as well number sets of jointing and fracture system. Generally, orientation of major structures and associated jointing and fracture system are trending N, NW and NE as shown in Figure 6.

Number of research studies conducted in the karst features in the eastern parts of Saudi Arabia (Hotzel, Saafin, Hussain et al. 2006 and Saner et al., 2005; Al-Sayari \& Zotl, 1978; Jado \& Johnson, 1983; Grouch et al., 1987; Edgell, 1990; Shehata et al., 1990, Shehata et al., 2007; Grosch et al., 1987; Holm, 1960; Powers et al., 1966; Chapman, 1978) reported that Karst features distributed in the karstic Formations in Al-Hassah and As Summan Plateau Region (e.g. Dam, Dammam and Um Er Radhuma formations) had been developed along the distinctive fractures, joints system, fault plans and folding system trending in $\mathrm{N}, \mathrm{NE}$ and NW direction as shown in Figure 7). These intersection discontinuities played an active role in controlling and formation of karst features at this region.

\subsubsection{Groundwater Setting}

The groundwater system studies in Hassah region as a part of the eastern province of Saudi Arabia and hosting the study area have been conducted a by different authors (Naimi, 1965; Italconsult, 1969, BRGM, 1977; Yazicigil et al., 1986; Allayla et al., 1987, De Jong et al., 1989; Rasheeduddin (1988), Al-Tokhais, 
B. A. Nawaz et al.

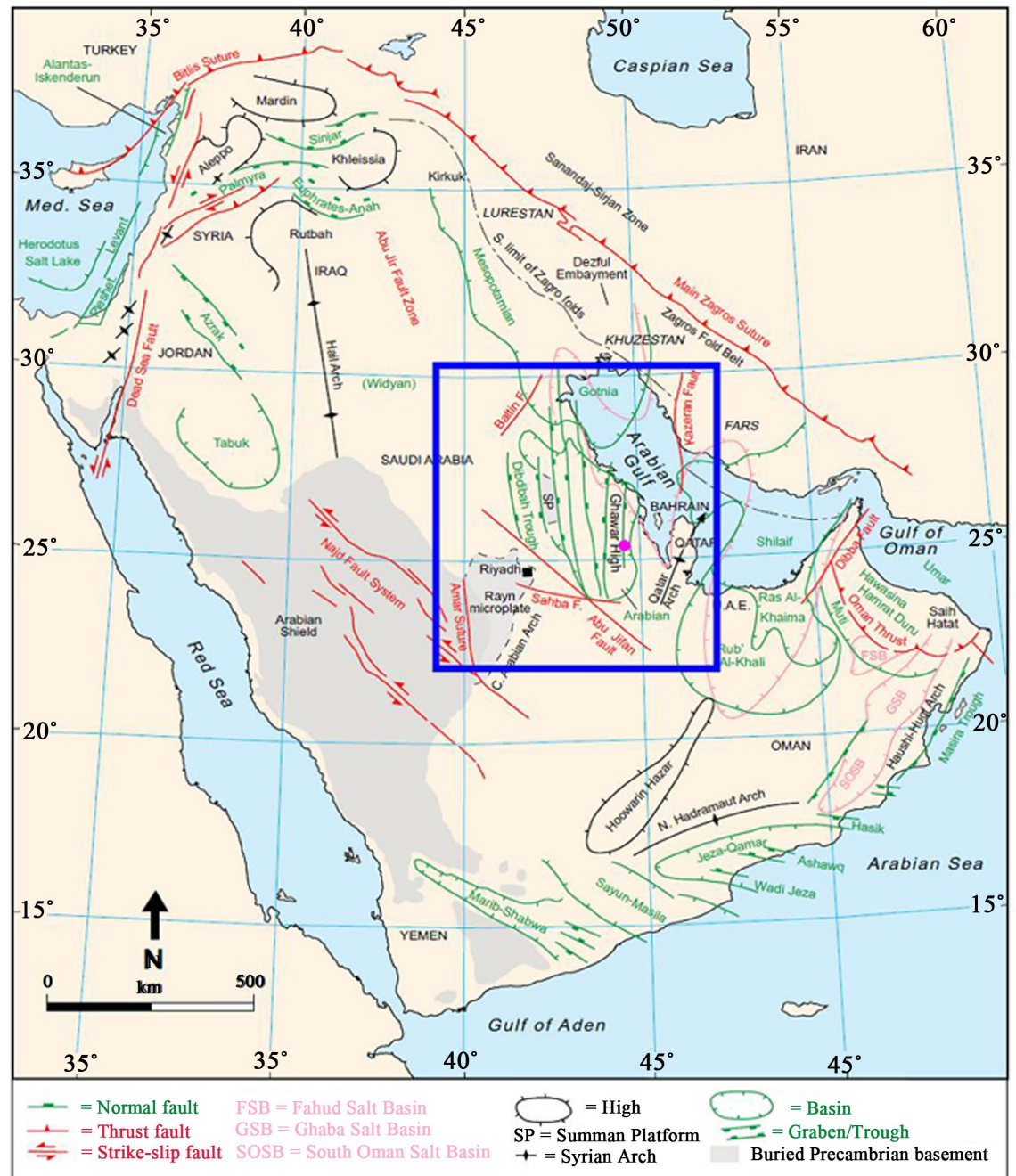

Figure 6. Showing the Major geological structures distributed in Al-Hasah Region that is hosting the Study Site (after Ziegler, 2001).

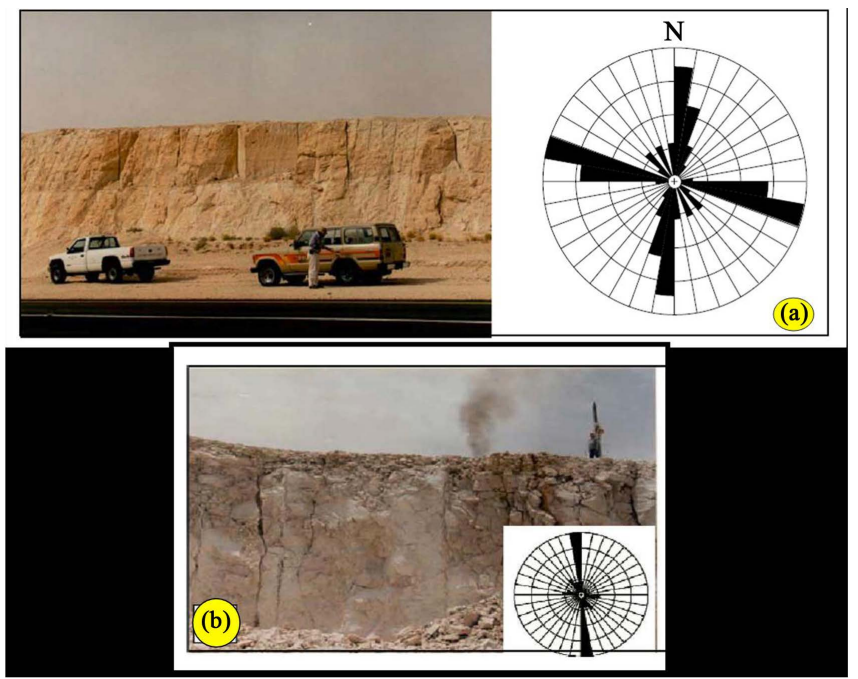

Figure 7. Fractures and Joint sets in karstic Formation, at Al-Hassah region, oriented in NE and NW directions. (a) Hofuf formation and (b) Dammam Formation. 
et al., 2008, and El-Mahmoudi, 2011), and reported that Hydrogeological system in Al-Hassah region consists of four partly interconnected aquifers as follows (Figure 8 and Figure 9):

- Neogene aquifer complex at the top-a mixture of Dammam Formation from some localities on top of the karstified fractured bedrock aquifers and

- Dammam aquifer complex, a partly karstified fractured aquifer,

- Umm Er Radhuma aquifer, a karstified fractured bedrock aquifer and

- Aruma aquifer at the base-a karstified fractured bedrock aquifer and of minor importance.

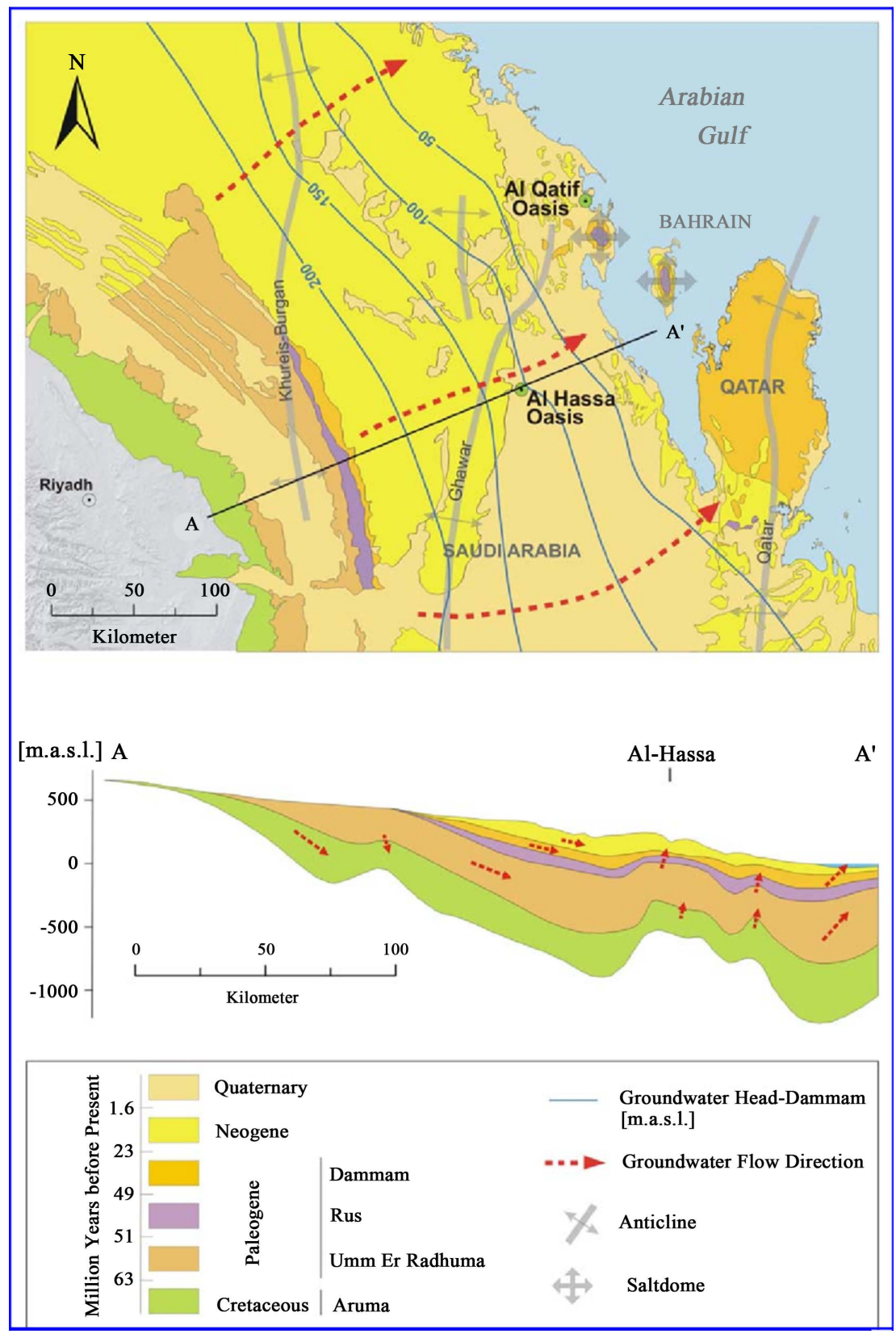

Figure 8. Geology \& hydrogeology at Al-Hassah Area, after Al Tokhais \& Rausch, 2008. 


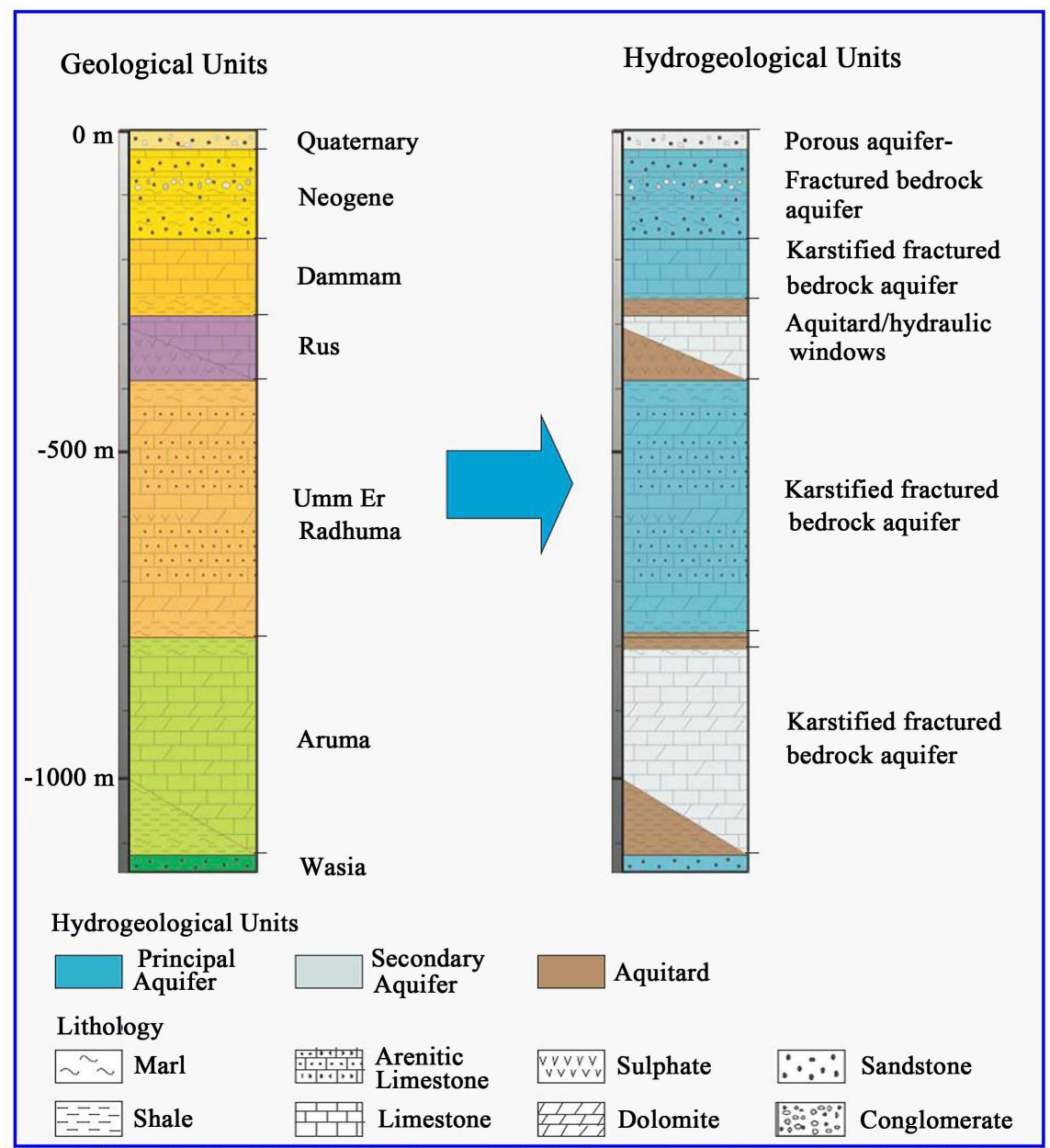

Figure 9. Schematic sketch, illustrating the hydrogeological units of the aquifer system at the area of study, after Al Tokhais \& Rausch, 2008.

As shown in the hydrogeological/Geological Map (Figure 7) that the groundwater at the Hassah region flows under the study site is directed from outcrop areas in the North and West to the south and east towards the Arabian Gulf.

It is known that in the past years, groundwater flow previously and supplied the city of Hofuf with water via the karst springs. Currently, the springs no longer flow due to un-regulated over-pumping of the Neogene aquifer that has reduced the groundwater level considerably (Edgell, 1993 and Nejem, 1994).

In conclusion, Hydrogeological study reveals that the study site as a part of the eastern Province of Saudi Arabia had received excessive amount of rainfall during the last pluvial period (Gutiérrez et al. and Nejem, 1994) that was percolated down thru the presence of fracture and joint systems and played an active role in karst formation at Al-Hassah region that is hosting the study site.

\subsection{Geotechnical Explorations}

\subsubsection{Subsurface Exploration and Field Testing}

Number of geotechnical site investigation projects have been conducted at the study site. Results of subsurface exploration, field testing and lab testing un- 
dertaken at the study site are summarized in Table 1 and Figure 10 and Figure 11.

Sample of subsurface profile at the study site showing the stratigraphical succession and underground cavity encountered between $14 \mathrm{~m}-17 \mathrm{~m}$ depth from existing ground surface.

Based on the information collected from previous field investigations, the stratigraphy at the site typically includes the following layers, from the top down as per Figure 12.

Table 1. Summary of subsurface exploration and field testing undertaken on the study site.

\begin{tabular}{|c|c|c|}
\hline Test & Description & Outcome \\
\hline Test Borings & $\begin{array}{l}\text { Six sets of borings were drilled } \\
\text { between } 1976 \text { and } 2009\end{array}$ & $\begin{array}{l}\text { Obtain geotechnical data for the } \\
\text { original foundation design at the } \\
\text { plant; try to identify potential } \\
\text { karst features; provide information } \\
\text { for a new turbine/pump }\end{array}$ \\
\hline $\begin{array}{l}\text { Borehole Video } \\
\text { Camera Studies }\end{array}$ & $\begin{array}{l}\text { Eight boreholes were imaged with a } \\
\text { video camera. The camera and a } \\
\text { supplemental light were slowly lowered } \\
\text { through the boreholes to film the walls. }\end{array}$ & $\begin{array}{l}\text { Cavities, fissures and other karst } \\
\text { features were panned by the } \\
\text { camera }\end{array}$ \\
\hline $\begin{array}{l}\text { Laboratory } \\
\text { Testing }\end{array}$ & $\begin{array}{l}\text { Laboratory testing was performed } \\
\text { as part of three previous } \\
\text { subsurface investigations. } \\
\text { Laboratory testing included } \\
24 \text { sieve tests; } 20 \text { hydrometer tests; } \\
22 \text { specific gravity; } 35 \text { natural moisture } \\
\text { contents; } 3 \text { unit weight tests; } \\
31 \text { Atterberg Limits; } 17 \text { unconfined } \\
\text { compression tests on soil samples; } \\
8 \text { Unconfined compression tests on rock }\end{array}$ & $\begin{array}{l}\text { Plotted Atterberg Limits on a } \\
\text { plasticity chart and natural } \\
\text { moisture content versus depth } \\
\text { are shown in Figure } 10 \text {. } \\
\text { Most of the test results are } \\
\text { clustered around the A-line on the } \\
\text { plot, with liquid limits ranging } \\
\text { from } 45 \text { percent to } 70 \text { percent and } \\
\text { classifying as } \mathrm{CH} \text { or } \mathrm{MH} \text { soils. } \\
\text { Natural moisture contents of the } \\
\text { soils ranged from } 7.2 \text { to } 33.2 \\
\text { percent with most of the values } \\
\text { between } 22 \text { and } 32 \text { percent. }\end{array}$ \\
\hline
\end{tabular}
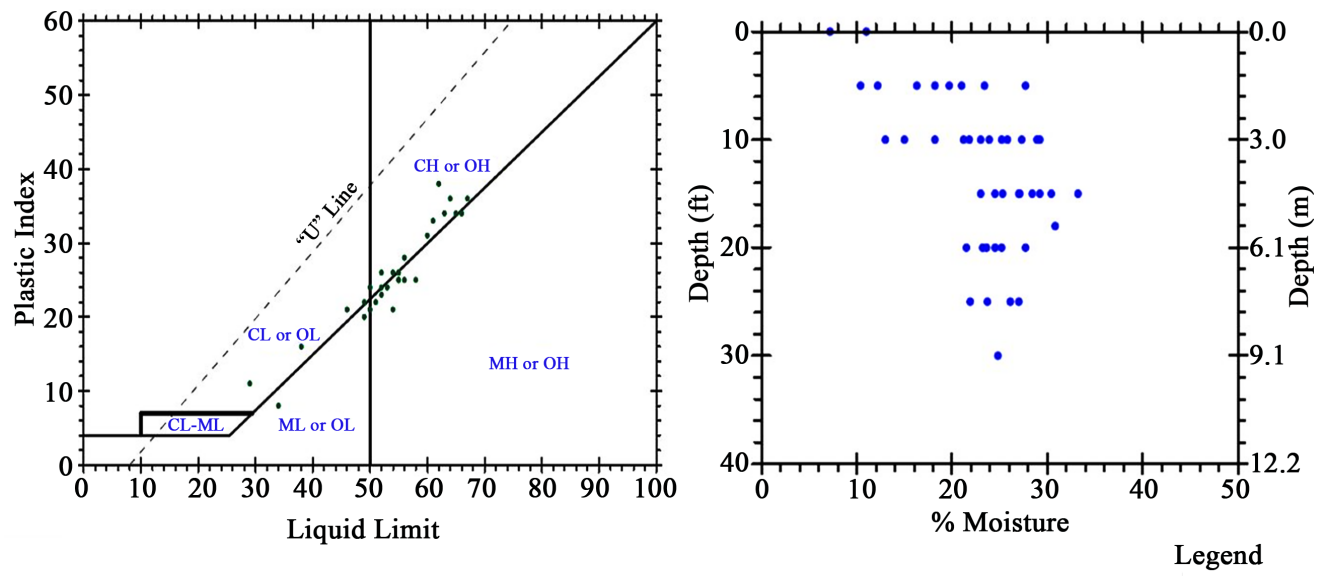

Figure 10. Laboratory Atterberg limits and moisture content test results. 


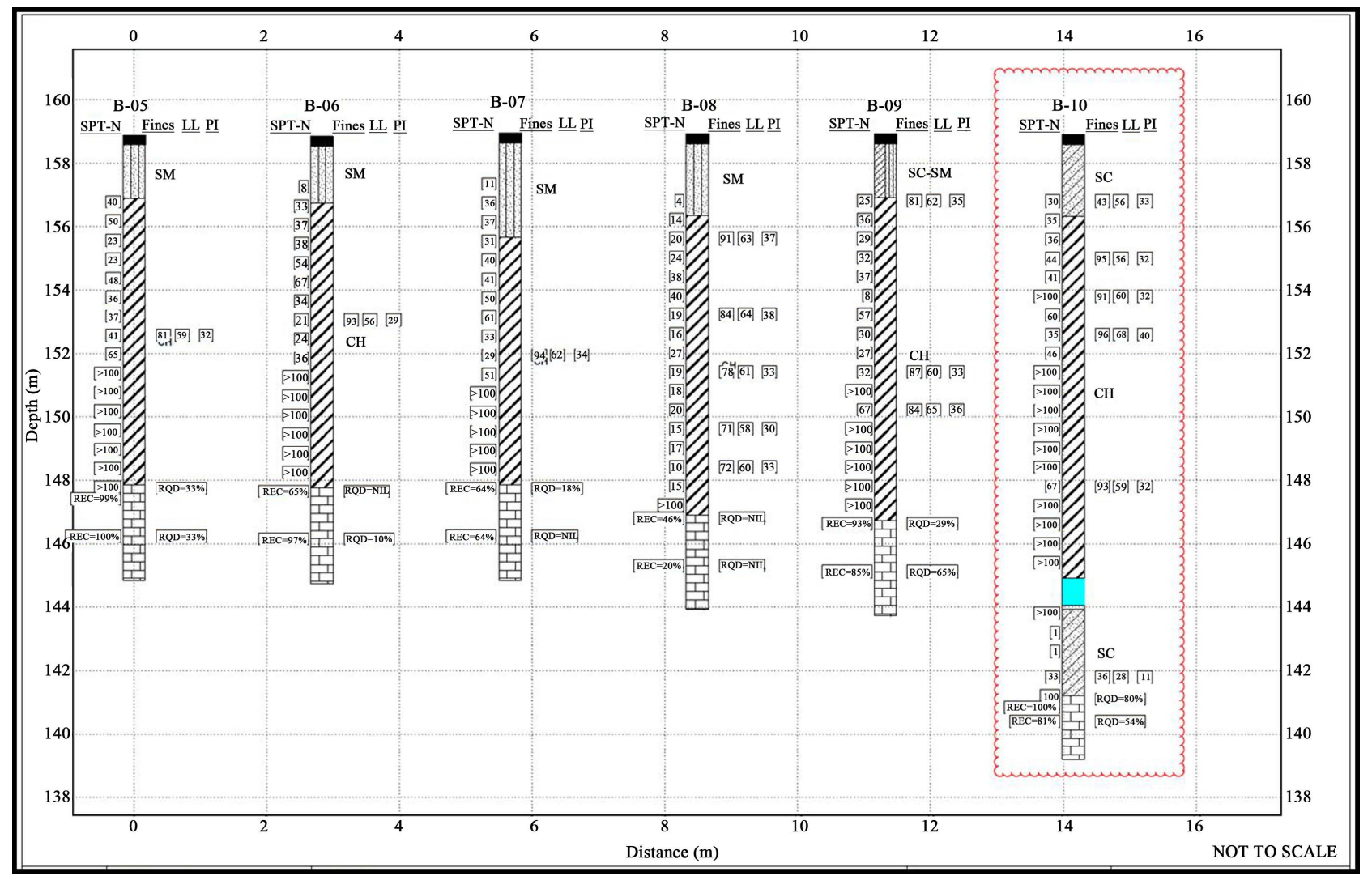

Figure 11. Sample of subsurface profile showing the stratigraphical succession at the study site (After Schnabel Engineering, 2012).

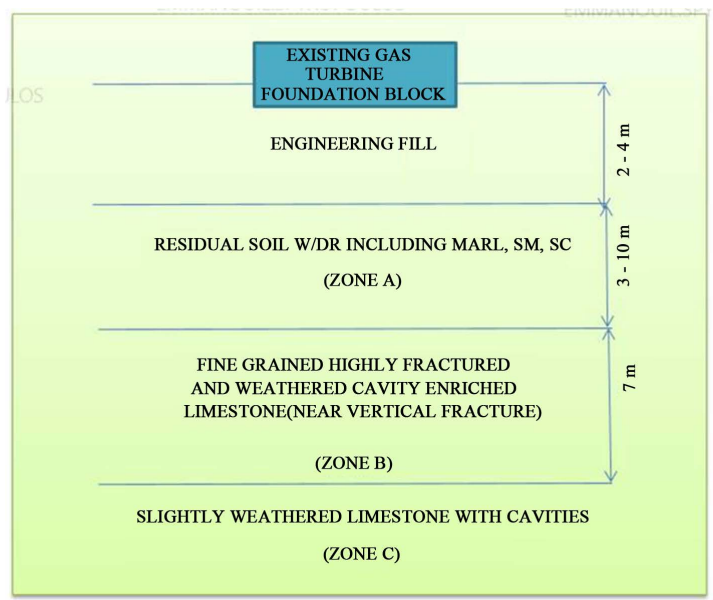

Figure 12. Generalized Subsurface Lithostratigraphical Succession at the study site.

\subsubsection{Geophysical Explorations}

Multiple geophysical technologies have been used on the western side and within the compound to evaluate the subsurface conditions with regard to karst features. A summary of the Geophysical methods applied is shown in Table 2.

\subsection{Risk Assessment}

\section{Approach}

The role of the risk assessment is to develop the probability of particular 
Table 2. Summary of geophysical investigations.

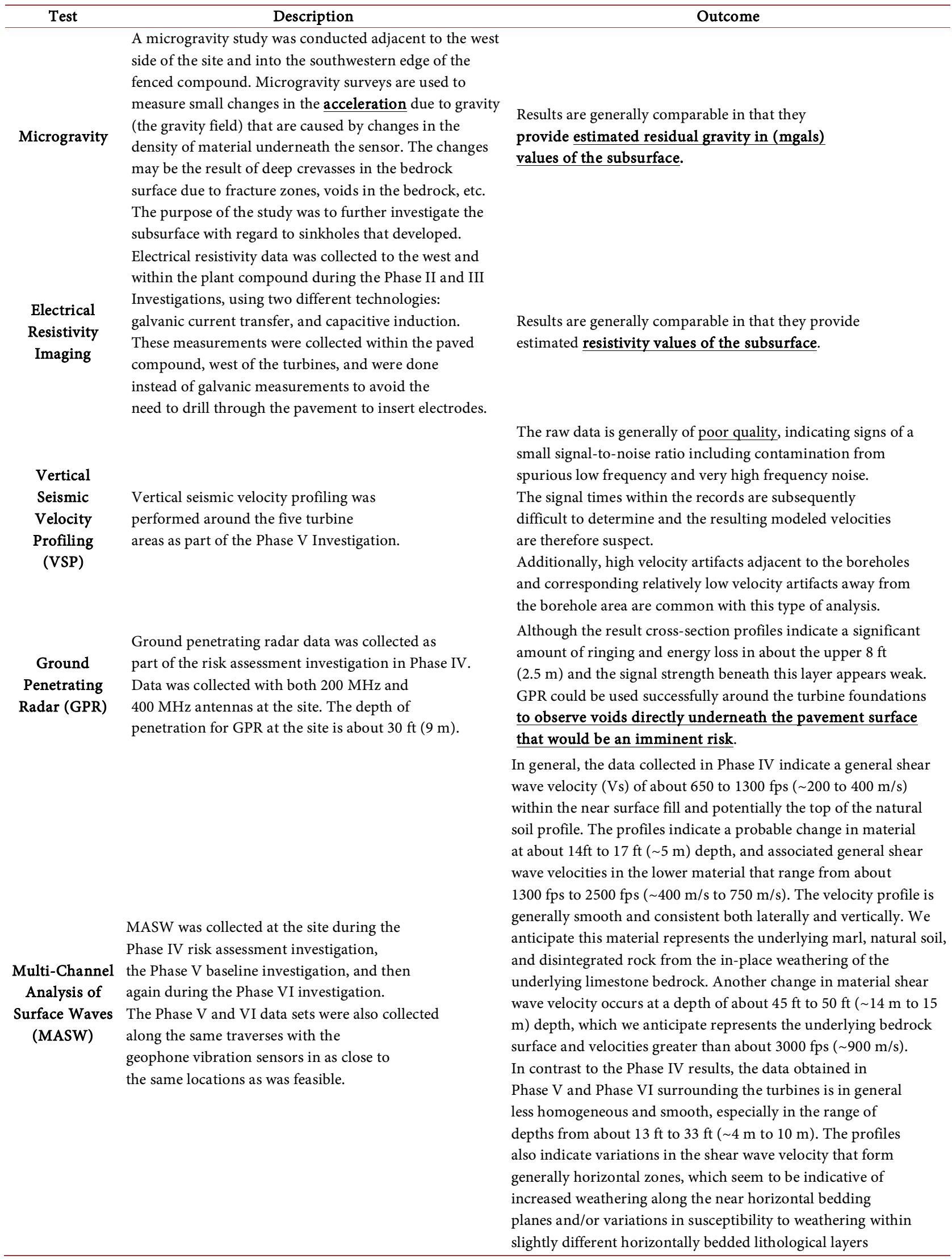


hazard that will affect failure in a system. Understanding the probability provides a tool for evaluating appropriate means to manage the risk by endorsing risk reduction measures or considering the potential consequences if failure occurs (Galve, et al., 2009, and Tolmachev \& Leonenko, 2011).

Failure may be defined to be any impact that significantly affects the system or critical parts of the system. Also, the risk probability may be quantitative, providing absolute probabilities that the hazards will occur (e.g., a 30\% chance of rain falling and making a land slide) or qualitative, providing relative probabilities of exposure to the hazard (e.g., a low, moderate, or high chance of something occurring). Quantitative risks can be estimated if failure mechanisms within the system are fully understood and enough statistical information is known about each mechanism that leads to the failure. These are commonly used in controlled systems where the materials are engineered, the properties are well known, and large amounts of statistical data are known about how the materials react in the specific conditions. However, karst regimes are complex systems that are seldom fully understood and vary significantly geographically, so that statistical information regarding how they react to often unidentified stresses is not fully known. Therefore, developing a truly quantitative assessment is not generally feasible, as is the case for this case. The risks must be qualitatively based on the available information, the history of similar situations, professional judgment, and an understanding of geologic and karst processes.

Before discussing the approach developed for the site, it is worth defining terms with regard to hazard, risk, failure, consequence, and residual risk (UNISDR (2004) and TC32-Technical Committee 32, 2004).

- Hazards are potentially harmful items or occurrences to persons, systems or other entities. An example of a karst hazard is a sinkhole.

- Risk is the uncertainty or probability of exposing persons, a system, or other entities to a hazard. Risk is often quantified in terms of probability. An example of risk is the probability that a sinkhole will develop underneath one of the critical structures on the site.

- Failure is defined as some level of impact the hazard could have. Generally, failure is also defined with respect to the consequence of the hazard even occurring. For example, failure could be defined at the site as any movement in the turbine foundations, or any karst-related event that requires stopping the turbine.

- Consequence in this usage is the quantifiable outcome of failure occurring at the site. This may include safety, cost, schedule, quality, or other quantifiable outcome. For example, the cost involved with performing an emergency repair and underpinning for one of the turbine foundations.

- Residual risk is the risk that remains after mitigation measures have been put in place. That is, even though actions may be made to prevent hazards from impacting the system, there will always be some risk as long as the hazards exist. 
The following process for has been developed for evaluating qualitative risk based on approaches used by the US Army Corps of Engineers for evaluating earthen structures and other similar structures. The approach consists of four phases, as shown below.

Hazard Analysis $\left.\left.\gg \begin{array}{c}\text { Probabilistic Risk } \\ \text { Analysis }\end{array}\right\rangle \begin{array}{c}\text { Failure Potential } \\ \text { Analysis }\end{array}\right\rangle \begin{gathered}\text { Consequence } \\ \text { Evaluation }\end{gathered}$

The results of each phase in the process are incorporated and overlaid on the following phases. The result of this process is a tool to evaluate the risk of karst development at each structure and the ability to consider the overall operational and cost consequences with respect to the risk. In addition to providing a model to develop a meaningful risk assessment, this model will provide information on how remedial measures will impact the overall risk and consequences to that risk.

1) The first phase, Hazard Analysis, includes developing a list of potential hazards with regard to karst based on professional judgment and experience.

2) The second phase, Probabilistic Risk Analysis, is to develop a list of risk factors that could potentially contribute to the overall risk of exposure to the hazard. During this phase, relative weights are given to each of the risk factors based on how instrumental they are with regard to exposing the hazard and according to the conditions at a particular location. Considerations that go into developing this are the proximity event, the probability of exposure, and the possible frequency of exposure. For example, if the hazard is a sinkhole, then significant potential for having water flow to that area has a large impact on the overall risk. However, the potential for that to happen may be very small, thereby mitigating the impact.

3) During the third phase, Failure Potential Analysis, the potential for failure in the event that the structures are exposed to the hazard is evaluated. This is an evaluation of the vulnerability of the structure to being exposed to the hazard. For example, the possibility that 1-m diameter sinkhole under the turbine foundation will damage the turbine seems to be relatively small as compared to a 10-m diameter sinkhole.

4) The fourth phase, the consequence of a failure for each hazard is estimated in terms of cost of repair, consequential costs due to lost time, safety, or schedule.

The available information does not adequately provide the clarity or density of information needed to conduct a complete risk analysis as discussed above. Multiple levels of information are either missing around the critical structures or contain sufficient ambiguity that prevents making a clear designation of the risk factors. Therefore, the designations were estimate conservatively or been omitted entirely where no information exists to help estimate the factor, and therefore including them would not serve to help define areas of greater risk. Additionally, not enough information were gathered regarding the operations and how a fail- 
ure of parts of the pump station, downstream systems, and upstream systems would be affected or the costs involved to develop a reasonable quantitative estimate of the consequences. This can be assisted when further development of this model be desired.

1) Hazard Assessment

Based on the understanding of the karst processes and the conditions on and underneath the site, the following are the expected hazards related to the underlying karstic conditions. Exposure to these hazards could potentially have negative impacts to both safety and operations at the facility (Zhou \& Beck, 2011; Buttrick \& van Schalkwyk, 1998, and Beynen, 2011).

a) An open sinkhole. This could result in loss of foundation support either vertically, laterally, or both, thereby negatively impacting the service of the turbine pumps. Also, sinkholes are, by nature, acute features in that they tend to manifest themselves rapidly and may need immediate action to prevent further damage to critical structures. Given the soil conditions at the site, dropout/cover collapse sinkholes are most likely to occur. Based on voids observed in the borehole videos, it is believed that voids in the soil may have developed via the physical erosion of water flowing through fractures in the soil.

b) A "hidden" sinkhole. These sinkholes are defined as those that develop underneath pavement or foundations that bridge over them, so that their presence is unknown. These could potentially lead to collapse as vehicles drive over top of the voids or eventual movement of critical structure foundations.

c) Long term subsidence due to consolidation of the underlying soil or loss of soil mass into open joints and voids in the underlying bedrock. This can result from ponding water which could eventually initiate such situation.

2) Probabilistic Risk Model

Attempts to generate susceptibility models using probabilistic methods are very rare (Yilmaz, 2007) and the assessment of their prediction capability (independent evaluation) has been presented only in a preliminary paper by Galve et al. (2008). Some of the criteria used to delineate susceptibility zonations include: sinkhole density (Brook \& Allison, 1986), nearest neighbor analysis, which provides a measure of the sinkhole clustering (Zhou et al., 2003), the establishment by means of expert criteria of threshold values for a given variable (Kaufmann \& Quinif, 2002; Gao \& Alexander, 2003), or the intuitive application of a scoring system to a group of conditioning factors (Brook \& Allison, 1986; Zhou et al., 2003; Jiang et al., 2001; Tolmachev et al., 2005).

\section{Results \& Discussion}

Results and findings of the above sections have been summarized and discussed in the following sections to identify, evaluate the expected and experienced karst hazard at an industrial facility plant; and then to recommend number of mitigation control measures to stop or minimize the karst risk that could endanger the facilities of studied plant placed on karst landform. 


\subsection{Natural Setting Encompssing the Project Sit and Suurounding Area and Kastification}

Results and findings of the Preliminary Investigation revealed that the natural setting encompassing the study site within Shedgum Plateau is vulnerable and susceptible for karstification based on the following:

The study site is located over lowland area (Depression) relatively to the surrounding uplifted escarpment that collected excessive amount of rainfall during the last pluvial period.

Rock type encountered at the study site mainly comprised of soluble carbonate rocks and having excessive number of joints.

Additionally pronounced sinkholes and other karst features have been observed at the study site and surrounding area.

Results of this preliminary Investigation at the study site and surrounding area indicated that the Al-Hasah area and study site is classified as karstification terrain and it is susceptible for Karst formation.

Results and findings of the preliminary Investigations revealed that karst features dominated at the study site and surrounding area are classified as mature karst (classes III - V). Therefore, more rigorous ground investigation with combination methods should be carried out to collect the required parameters that are needed for hazard/risk assessment and consequently to provide the most adequate mitigation measures (Waltham, et al., 1988, Waltham \& Fookes, 2003, and Thomas \& Roth, 1999).

\subsection{Geotechnical, Geophysical Characteristics of Earth Material and Risk Assessment of Karst at the Project Site}

Have been integrated to determine the factors influencing the potential of karst hazards experienced at the project site are summarized in the following sections:

\subsubsection{Factors of Risk and Hazard of Karst}

This work presents a method of quantitatively developing and independently testing sinkhole susceptibility and hazard models in a $50 \mathrm{~km}^{2}$ sector of the Ebro Valley evaporite karst in northeast Spain.

Risk factors that contribute to the potential exposure to the above hazards are generally related to the existing geologic conditions underlying the location, water conditions both underlying the site and management of surface water at the site, and changes made to the natural site conditions. A list of factors was obtained for each of those broad categories.

The list of risk factors is reduced based on the historical information (boring logs, borehole video footage, laboratory test results, and geophysical surveys) regarding the subsurface conditions underlying the turbines. Risk factors that could not be evaluated due to lack of information, or were not applicable to this site, were eliminated from consideration. Risk factors eliminated from this analysis due to lack of information may still substantially contribute to the develop- 
ment of hazards on site. The following is the reduced list of risk factors. Sources of information were included in parentheses after each.

1) Geological Factors: Depth to bedrock (test borings and geophysical results), Overburden soil potential for raveling (laboratory testing, BHs), Overburden soil potential for desiccation (laboratory testing), Potential for near-surface bedrock, disintegrated rock, and boulders (test boring logs and geophysics), Quality and fracturing of rock within the top $5 \mathrm{~m}$ of bedrock (test boring, video logs, and geophysics), Presence and size of known existing voids within soil (test boring and video logs), Presence and size of known existing voids within rock (test boring and video logs), The proximity of known existing voids to the structure (test boring and video logs), History of past sinkholes and depressions (reports and interviews), Soft zones in underlying soil (geophysics), Decrease in shear wave velocity within the underlying soil over time (geophysics), and Bedrock orientation (test borings, video logs, and published geologic papers)

2) Groundwater factors: Depth to groundwater (published papers, hydrologic report, and interviews), Groundwater pumping history (published papers and interviews), and Evidence of past near surface groundwater flow (video logs)

3) Surface Water and Infiltration factors: Existing and historic pipe leaks (interviews, site plans), Existing and historic process water discharge (reports and interviews), and Storm water ponding and storm water runoff on site (site observations, rep

4) Site Features factors: Existing and former buried structures and utilities (interviews and site plans), Soil disturbance by site activities (interviews), and Impervious surfaces (historical and current)

5) Data Coverage factor: This factor is introduced to provide additional risk depending on the relative amount and general quality of the data in the areas in order to counteract the impact of data density. Areas with low amounts of information have higher associated risk than areas without information. It is worth noting that some areas around the turbines have much more information regarding the subsurface conditions than others. Although attempt was made to prevent artificially increasing the risk in any particular area based on the fact that those areas had more investigations, it is anticipated that the distribution of information has an impact on the results. For example, an area with a test boring may have a higher risk than an area without a test boring because a void was encountered in the test boring. However, it would be misleading to believe that the area without a test boring therefore truly has a lower risk. Perhaps no void was encountered because test borings were not conducted in that location.

\subsubsection{Risk and Hazard of Karst Analysis at the Project Site}

Each of the above risk factors were evaluated for the various critical structures, using a relative weighting based on the severity of the conditions at the specific location as discussed by Galve et al., 2009.

Following is a discussion of each risk factor and the approach used to assign the weighting: 


\section{6) Depth to bedrock}

The size of the surface expression of a sinkhole is partially controlled by the depth to bedrock and the thickness of the soil cover. Shallow depth to bedrock typically results in smaller or narrower sinkholes at the ground surface. Review of the historic borings revealed that no consistent criteria were used to define the top of bedrock or to determine the appropriate depth to start coring rock. Some investigations used SPT N-values to define the top of rock and the start of rock coring. Other investigations started coring within a few meters of the ground surface or as deep as $20 \mathrm{~m}$ below the ground surface. No explanation was provided in these reports for how the depth to start coring was determined. After plotting the depth at which rock coring began for each borehole, no clear trend or correlation was observed due to the poor quality of the data. Reviewing the video footage cannot result in a clear delineation between soil and rock. The poor quality data limits the use of this data in the determination of risk.

7) Overburden soil potential for raveling

The density and plasticity (i.e., cohesion) of the overburden soils determine in part how erodible the soils are and how much potential the soils have to develop shrink-swell cracks. Soils with lower levels of cohesion (granular soils like sand and fine-grained soils like silt) are more prone to erosion. High plasticity soils are more prone to shrink-swell behavior and shrinkage cracks. Review of the historic borings revealed that most of the previous investigations did not collect soil samples during drilling for classification and laboratory testing. In addition, the descriptions on some borings were inconsistent, such as classifying silty sand with limestone fragments to be marl fill. Laboratory test results available indicate that the overburden soils generally consist of silty (ML, MH), sandy (SM, SC), and clayey $(\mathrm{CL}, \mathrm{CH})$ soils. It is assumed that this is a uniform risk across the site.

8) Overburden soil potential for desiccation

Fine grained soil such as clay and silt have the ability to reduce in volume upon drying. This is even more true for fat (highly plastic) clay and highly plastic silt and more so with clay than silt. Review of laboratory data from previous reports provided relative rating of the soil on site to desiccate.

9) Potential for near-surface bedrock, disintegrated rock, and boulders

The presence of a capstone layer on the rock can create cover-collapse "caprock" sinkholes. Additionally, near surface boulders and thick layers of disintegrated rock are potential sinks for soil to ravel into them and form sinkholes. Capstone bedrock and boulders were not observed in the boring logs on video footage and therefore are not anticipated to be a significant risk factor. Disintegrated rock was estimated based on geophysical results.

10) Quality and fracturing of rock within the top $5 \mathrm{~m}$ of bedrock

Highly fractured rock near the surface of the bedrock allows for easier infiltration of water into the bedrock. In general, highly fractured rock was observed at shallow depths in all borings. Due to the inconsistent methods used to define top of rock in the previous exploration programs, it was not possible to determine if this was within the top $5 \mathrm{~m}$ of bedrock or residual soils and disintegrated rock. It 
is assumed that this is a uniform risk across the site.

11) Presence and size of existing voids within soil

Voids observed within the overburden soils and disintegrated rock indicate that soil is raveling into voids in the bedrock below.

12) Presence and size of existing voids within rock

Overburden soil may fall into existing voids in the bedrock below. Due to the inconsistent methods used to drill and log historic borings, voids considered are only those observed to be open in the video footage or specifically noted as open voids on the logs. Most of the open voids were encountered at depths deeper than $10 \mathrm{~m}$ below the ground surface. Open voids were observed in few locations within $10 \mathrm{~m}$ of the ground surface.

13) The proximity of existing voids to the structure

The closer existing voids are to existing structures, the greater the risk that the voids may cause damage to existing structures. Open voids were observed under the north end and middle of all turbines.

14) History of past sinkholes and depressions on site

Sinkholes and depressions that have previously appeared on the site indicate that there are solution features below the ground surface that are active. A sinkhole developed in 2002 on the west side of the site and the southwest area of the site near the biocide tanks.

15) Soft zones in underlying soil (geophysics)

Soft zones just above the bedrock surface, sometimes called epi-karst zones, are common in karst terrain. They are the result of the underlying bedrock chemical weathering and eroding at the base of the natural soil and leaving non-soluble portions of the parent rock. This residual soil is therefore under-consolidated and has the potential for subsidence due to the weight of the soil above it and/or the addition of loads from structures at the ground surface. Evaluation was made to the shear wave velocities in the underlying soil to estimate if such zones exist.

16) Decrease in shear wave velocity within the underlying soil over time

Reduction in shear wave velocity may correspond to a similar reduction in stiffness in the underlying soil. This information was obtained by comparing the shear wave velocity values collected in 2007 and 2011.

\section{7) Bedrock orientation}

Dipping bedrock forms pinnacles at the rock surface and typically smaller sinkholes than horizontally-bedded rock, which is more prone to collapse sinkholes. In addition, infiltrating surface water can become trapped and flow down between the bedding layers, creating preferred solution channels. Based on published regional geology descriptions, the orientation of the bedding is considered horizontal. This is assumed to be a uniform risk across the site.

\section{8) Depth to groundwater}

Many sinkholes are triggered by changes in capillary forces in the pore spaces of the overburden soil when the depth to groundwater varies. In all borings, groundwater was not encountered. This is not unexpected due to the regional pumping of groundwater and the impervious pavement covering portions of the 
site. Therefore, this is assumed to be a uniform risk across the site.

\section{9) Groundwater pumping history}

Similarly, the drawdown of groundwater levels due to pumping can trigger sinkhole activity. The interviews with site personnel reveals that the groundwater has significantly dropped in the area in the years after the plant was constructed due to pumping. However, no groundwater was observed in the subsurface explorations from 1976 to present. This is assumed to be a uniform risk across the site.

20) Evidence of past shallow groundwater flow

Evidence of past groundwater flow can indicate preferred water channels. Review of video footage revealed that near surface materials were coated with a calcite crust.

\section{1) Existing and historic pipe leaks}

Pipe leaks is a source of water that can drive the downward migration of soil into voids triggering sinkholes at the surface. A pinhole leak was developed in the water transmission pipes on the western side of the compound prior to abandoning them below ground.

22) Existing and historic process water discharge

Discussions with site staff reveals that process water is temporarily stored in ponds on the east side of the site. Also, a release of water used to clean biocide tanks in 2006 was allowed to discharge to the western side of the site triggering sinkholes.

23) Storm water ponding and storm water swales and channels

Storm water ponding and runoff, if allowed to percolate into the soil, can drive the downward migration of soil into voids triggering sinkholes at the surface. It was observed that there are several areas on the site where surface water and/or storm water has been allowed to pond or overflow swales, channels, and depressions.

24) Existing and formerly buried structures and utilities

Existing and formerly buried structures can create preferred drainage channels or divert water flow. The majority of the water transmission pipes within the compound were buried until they were replaced in 1992 and 2008. We understand that the original pipes were abandoned in place but that pipes near the existing control room were excavated and removed when the building was constructed in its current location in 2008. The excavations were reportedly backfilled with soil, sand and pipe bedding material.

\section{5) Soil disturbance by site activities}

Soil disturbance by earthwork activities on site can change the stress levels and alter drainage pathways. Fill soils were reported at the top of some of the historic borings. In addition, the surface of the site had to be modified to create the pad for the pumping station, the storm water ponds, and other structures.

\section{6) Changes to area covered by impervious surfaces}

Impervious surfaces can concentrate infiltration of storm water runoff to small areas. In addition, large impervious surfaces can reduce the surface water infil- 
tration overall at the site lowering the groundwater table locally. The majority of the pumping station has been built on a large relatively impervious concrete pad eliminating storm water infiltration under the center of the plant and concentrating it at the edges and channels.

27) Previous sinkhole identification and remediation activities (drilling, grouting, void filling, etc.)

Previous exploration and remediation can create and modify existing drainage pathways. The boreholes from previous exploration programs were left unfilled at the end of work. These open boreholes create new conduits for groundwater.

\subsubsection{Risk and Hazard of Karst Calculation and Evaluation at the Project Site}

Summarizes the criteria used to calculate risk for each risk factors. Each risk factor was assessed based on its likelihood and impact, as per the risk matrix shown in Table 3 and Table 4.

Table 3. Risk assessment analysis-criteria for risk factors.

\begin{tabular}{|c|c|c|c|c|c|}
\hline & \multirow{3}{*}{ Criteria } & \multicolumn{4}{|c|}{ Risk Level (Assigned Points) } \\
\hline & & \multirow{2}{*}{$\frac{1}{\text { (Low Risk) }}$} & \multirow{2}{*}{2} & \multirow{2}{*}{3} & \multirow{2}{*}{$\begin{array}{c}4 \\
\text { (High Risk) }\end{array}$} \\
\hline & & & & & \\
\hline & 1. Depth to bedrock (m) & $>15$ & $10-15$ & $5-10$ & $<5$ \\
\hline & 2. Soil Raveling Potential & $\mathrm{CH}$ & $\mathrm{NH} / \mathrm{CL}$ & $\mathrm{SC} / \mathrm{SM} / \mathrm{ML}$ & SP/SW \\
\hline & 3. Soil Desiccation Potential & $\mathrm{SP} / \mathrm{SW}$ & $\mathrm{SC} / \mathrm{SM} / \mathrm{ML}$ & $\mathrm{MH} / \mathrm{CL}$ & $\mathrm{CH}$ \\
\hline & 4. Potential for Boulders & - & No Cap rock & - & Cap rock \\
\hline & 5. Fracturing of top $5 \mathrm{~m}$ of Rock & Unfractured & $\begin{array}{l}\text { Slightly } \\
\text { Fractured }\end{array}$ & $\begin{array}{l}\text { Moderate } \\
\text { Fractured }\end{array}$ & $\begin{array}{l}\text { Highly } \\
\text { Fractured }\end{array}$ \\
\hline \multirow[t]{8}{*}{ Geology } & 6. Voids and Fissures in Soil & - & No & - & Yes \\
\hline & 7. Depth of Void (m) & $>15$ & $10-15$ & $5-10$ & $<5$ \\
\hline & 8. Proximity of Voids (m) & $>30$ & $15-30$ & $3-15$ & $<3$ \\
\hline & 9. History of Sinkholes, within $30 \mathrm{~m}$ & - & - & - & Yes \\
\hline & 10. Shear Wave Velocity $(\mathrm{m} / \mathrm{sec})$ & $>400$ & $250-400$ & $150-250$ & $<150$ \\
\hline & 11. Decrease in Shear Wave Velocity $(\mathrm{m} / \mathrm{sec})$ & $<70$ & $70-140$ & $140-250$ & $>250$ \\
\hline & 12. Bedrock Orientation & Horizontal & Slight Dip & Moderate Dip & Steep Dip \\
\hline & 13. Depth to Groundwater (m) & $>15$ & $10-15$ & $5-10$ & $<5$ \\
\hline \multirow[t]{3}{*}{ Groundwater } & 14. Groundwater Pumping History & Never & Stopped & Deep & Shallow \\
\hline & 15. Groundwater Flow in Voids & - & No & - & Yes \\
\hline & 16. Pipe Leak, within $30 \mathrm{~m}$ & No & - & - & Yes \\
\hline \multirow{3}{*}{$\begin{array}{l}\text { Surface Water } \\
\& \text { Infiltration }\end{array}$} & 17. Process Water Discharge, within $30 \mathrm{~m}$ & - & - & - & Yes \\
\hline & 18. Storm water Ponding, within $30 \mathrm{~m}$ & - & - & - & Yes \\
\hline & 19. Buried Structures, within $30 \mathrm{~m}$ & - & - & - & Yes \\
\hline \multirow[t]{2}{*}{ Site Features } & 20. Soil Disturbance, within $30 \mathrm{~m}$ & - & - & - & Yes \\
\hline & 21. Impervious Surfaces, within $30 \mathrm{~m}$ & No & - & - & Yes \\
\hline General & 22. Data Coverage & Extensive & Some & Limited & Sparse \\
\hline
\end{tabular}


Table 4. Risk assessment matrix.

\begin{tabular}{lcccc}
\hline & Very Likely & 3 & 4 & 5 \\
Likelihood & Likely & 2 & 3 & 4 \\
& Unlikely & 1 & 2 & 3 \\
& Low & Moderate & High \\
& & Impact & \\
& &
\end{tabular}

Appropriate weighting for each of the risk factors is used for the calculations of the risks for both sinkhole and subsidence in Table 5 and Table 6, respectively.

According to the risk model for sinkholes, the highest risk for exposure to a sinkhole hazard is at the north and south ends of GT3. The northern side of GT2 also has a high risk. Results and findings showed that the southern side of GT3 is ranked number one as the area with the highest risk. The driving factors at the north end of GT5 are "voids seen in the soil" and "proximity to voids." The lowest risk is at GT4 and specifically the southern end of GT4.

Regarding subsidence, the northern and southern portions of GT3 have the highest risk in similar fashion to the sinkhole risk. However, the ranking at the northern end of GT5 decreased slightly relative to the other turbines. The lowest risk area is the northern portion of GT4. Results of risk assessment showed the relative risk of subsidence by area and the relative rank each area has. Numbers indicate relative rank in risk from highest to lowest.

In general, the eastern and northern sides of the turbine area seem to have greater risk for developing sinkholes and subsidence than the west. This assessment agrees with reports submitted previously by $\mathrm{Al}$ Jahat Co. and Geophysical Services, LTD. Also, the primary risk factors that seem to drive the risk at the site, given the available information, are the depth to bedrock, voids observed in the soil, the depth to voids in the underlying bedrock, proximity of voids in the subsurface to the structures, soft zones underlying the site, and the decrease in shear wave velocities underneath the structure foundations.

\subsubsection{Risk and Hazard of Karst Reduction at the Project Site}

Although it is not feasible to remove the hazards from the site, there are two general ways to reduce the risk of exposing the critical structures to those hazards: learn more about the conditions to reduce ambiguity and subsequent conservatism, prevent the hazards from manifesting themselves by preventive measures, or reduce the impact of the hazards on the structure in the event of manifestations.

1) Data Gaps

Some potentially significant risk factors were removed from the risk model due to inadequate information to evaluate them. Including them would not have added contrast to specific areas on the site because the weighting values for the entire site would likely be similar. Additionally, there is limited information on 
Table 5. Risk assessment analysis—sinkhole hazard.

\begin{tabular}{|c|c|c|c|c|c|c|c|c|c|c|c|c|c|c|c|c|}
\hline \multirow{3}{*}{ Criteria } & \multirow{3}{*}{$\begin{array}{l}\text { Relative } \\
\text { Weight }\end{array}$} & \multicolumn{15}{|c|}{ Structure Name } \\
\hline & & \multicolumn{3}{|c|}{ GT-1 } & \multicolumn{3}{|c|}{ GT-2 } & \multicolumn{3}{|c|}{ GT-3 } & \multicolumn{3}{|c|}{ GT-4 } & \multicolumn{3}{|c|}{ GT-5 } \\
\hline & & $\mathbf{N}$ & $\mathbf{M}$ & $S$ & $\mathrm{~N}$ & $\mathbf{M}$ & $S$ & $\mathbf{N}$ & $\mathbf{M}$ & $S$ & $\mathbf{N}$ & $\mathbf{M}$ & $S$ & $\mathbf{N}$ & $\mathbf{M}$ & $S$ \\
\hline 1. Depth to bedrock (m) & 3 & 3 & 3 & 3 & 3 & 3 & 3 & 3 & 3 & 3 & 3 & 3 & 3 & 2 & 3 & 3 \\
\hline 2. Soil Raveling Potential & 2 & 1.5 & 1.5 & 1.5 & 1.5 & 1.5 & 1.5 & 1.5 & 1.5 & 1.5 & 1.5 & 1.5 & 1.5 & 1.5 & 1.5 & 1.5 \\
\hline 3. Soil Desiccation Potential & 3 & 3.5 & 3.5 & 3.5 & 3.5 & 3.5 & 3.5 & 3.5 & 3.5 & 3.5 & 3.5 & 3.5 & 3.5 & 3.5 & 3.5 & 3.5 \\
\hline 4. Potential for Boulders & 2 & 2 & 2 & 2 & 2 & 2 & 2 & 2 & 2 & 2 & 2 & 2 & 2 & 2 & 2 & 2 \\
\hline 5. Fracturing of top $5 \mathrm{~m}$ of Rock & 2 & 4 & 4 & 4 & 4 & 4 & 4 & 4 & 4 & 4 & 4 & 4 & 4 & 4 & 4 & 4 \\
\hline 6. Voids and Fissures in Soil & 4 & 2 & 2 & 2 & 4 & 2 & 2 & 4 & 2 & 4 & 2 & 2 & 2 & 4 & 2 & 2 \\
\hline 7. Depth of Void (m) & 3 & 2 & 2 & 2 & 2 & 2 & 2 & 2 & 3 & 4 & 2 & 2 & 1 & 2 & 2 & 2 \\
\hline 8. Proximity of Voids (m) & 4 & 4 & 2 & 3 & 4 & 3 & 2 & 4 & 3 & 3 & 4 & 3 & 3 & 4 & 3 & 3 \\
\hline 9. History of Sinkholes, within $30 \mathrm{~m}$ & 3 & 0 & 0 & 0 & 0 & 0 & 0 & 0 & 0 & 0 & 0 & 0 & 0 & 0 & 0 & 0 \\
\hline 10. Shear Wave Velocity $(\mathrm{m} / \mathrm{sec})$ & 2 & 3 & 3 & 4 & 3 & 3 & 3 & 3 & 3 & 3 & 2 & 3 & 4 & 3 & 3 & 3 \\
\hline 11. Decrease in Shear Wave Velocity $(\mathrm{m} / \mathrm{sec})$ & 2 & 3 & 3 & 2 & 4 & 4 & 2 & 4 & 4 & 4 & 1 & 1 & 1 & 1 & 1 & 1 \\
\hline 12. Bedrock Orientation & 3 & 1 & 1 & 1 & 1 & 1 & 1 & 1 & 1 & 1 & 1 & 1 & 1 & 1 & 1 & 1 \\
\hline 13. Depth to Groundwater (m) & 3 & 1 & 1 & 1 & 1 & 1 & 1 & 1 & 1 & 1 & 1 & 1 & 1 & 1 & 1 & 1 \\
\hline 14. Groundwater Pumping History & 2 & 3 & 3 & 3 & 3 & 3 & 3 & 3 & 3 & 3 & 3 & 3 & 3 & 3 & 3 & 3 \\
\hline 15. Groundwater Flow in Voids & 2 & 2 & 2 & 2 & 2 & 2 & 2 & 2 & 2 & 4 & 2 & 2 & 2 & 2 & 2 & 2 \\
\hline 16. Pipe Leak, within $30 \mathrm{~m}$ & 4 & 0 & 0 & 0 & 0 & 0 & 0 & 0 & 0 & 0 & 0 & 0 & 0 & 0 & 0 & 0 \\
\hline 17. Process Water Discharge, within $30 \mathrm{~m}$ & 3 & 0 & 0 & 0 & 0 & 0 & 0 & 0 & 0 & 0 & 0 & 0 & 0 & 0 & 0 & 0 \\
\hline 18. Storm water Ponding, within $30 \mathrm{~m}$ & 4 & 3 & 3 & 3 & 3 & 3 & 3 & 3 & 3 & 3 & 3 & 3 & 3 & 3 & 3 & 3 \\
\hline 19. Buried Structures, within $30 \mathrm{~m}$ & 3 & 1 & 1 & 1 & 1 & 1 & 1 & 1 & 1 & 1 & 1 & 1 & 1 & 2 & 2 & 2 \\
\hline 20. Soil Disturbance, within $30 \mathrm{~m}$ & 2 & 0 & 0 & 0 & 0 & 0 & 0 & 0 & 0 & 0 & 0 & 0 & 0 & 0 & 0 & 0 \\
\hline 21. Impervious Surfaces, within $30 \mathrm{~m}$ & 3 & 1 & 1 & 1 & 1 & 1 & 1 & 1 & 1 & 1 & 1 & 1 & 1 & 1 & 1 & 1 \\
\hline \multirow[t]{3}{*}{ 22. Data Coverage } & 2 & 3 & 4 & 3 & 2 & 4 & 4 & 3 & 4 & 3 & 4 & 4 & 3 & 3 & 4 & 4 \\
\hline & Total Risk & 117 & 111 & 113 & 125 & 117 & 109 & 127 & 120 & 133 & 113 & 111 & 108 & 121 & 114 & 114 \\
\hline & Ranking & 6 & 9 & 8 & 3 & 6 & 10 & 2 & 5 & 1 & 8 & 9 & 11 & 4 & 7 & 7 \\
\hline
\end{tabular}

N: North side, M: Middle side, S: South side.

Table 6. Risk assessment analysis-subsidence hazard.

\begin{tabular}{|c|c|c|c|c|c|c|c|c|c|c|c|c|c|c|c|c|}
\hline \multirow{3}{*}{ Criteria } & \multirow{3}{*}{$\begin{array}{l}\text { Relative } \\
\text { Weight }\end{array}$} & \multicolumn{15}{|c|}{ Structure Name } \\
\hline & & \multicolumn{3}{|c|}{ GT-1 } & \multicolumn{3}{|c|}{ GT-2 } & \multicolumn{3}{|c|}{ GT-3 } & \multicolumn{3}{|c|}{ GT-4 } & \multicolumn{3}{|c|}{ GT-5 } \\
\hline & & $\mathrm{N}$ & $\mathbf{M}$ & $S$ & $\mathrm{~N}$ & $\mathbf{M}$ & $S$ & $\mathbf{N}$ & $\mathbf{M}$ & $S$ & $\mathrm{~N}$ & $\mathbf{M}$ & $S$ & $\mathrm{~N}$ & $\mathbf{M}$ & $s$ \\
\hline 1. Depth to bedrock (m) & 2 & 3 & 3 & 3 & 3 & 3 & 3 & 3 & 3 & 3 & 3 & 3 & 3 & 2 & 3 & 3 \\
\hline 2. Soil Raveling Potential & 2 & 1.5 & 1.5 & 1.5 & 1.5 & 1.5 & 1.5 & 1.5 & 1.5 & 1.5 & 1.5 & 1.5 & 1.5 & 1.5 & 1.5 & 1.5 \\
\hline 3. Soil Desiccation Potential & 2 & 3.5 & 3.5 & 3.5 & 3.5 & 3.5 & 3.5 & 3.5 & 3.5 & 3.5 & 3.5 & 3.5 & 3.5 & 3.5 & 3.5 & 3.5 \\
\hline 4. Potential for Boulders & 2 & 2 & 2 & 2 & 2 & 2 & 2 & 2 & 2 & 2 & 2 & 2 & 2 & 2 & 2 & 2 \\
\hline 5. Fracturing of top $5 \mathrm{~m}$ of Rock & 2 & 4 & 4 & 4 & 4 & 4 & 4 & 4 & 4 & 4 & 4 & 4 & 4 & 4 & 4 & 4 \\
\hline
\end{tabular}




\section{Continued}

\begin{tabular}{|c|c|c|c|c|c|c|c|c|c|c|c|c|c|c|c|c|}
\hline 6. Voids and Fissures in Soil & 2 & 2 & 2 & 2 & 4 & 2 & 2 & 4 & 2 & 4 & 2 & 2 & 2 & 4 & 2 & 2 \\
\hline 7. Depth of Void (m) & 2 & 2 & 2 & 2 & 2 & 2 & 2 & 2 & 3 & 4 & 2 & 2 & 1 & 2 & 2 & 2 \\
\hline 8. Proximity of Voids (m) & 2 & 4 & 2 & 3 & 4 & 3 & 2 & 4 & 3 & 3 & 4 & 3 & 3 & 4 & 3 & 3 \\
\hline 9. History of Sinkholes, within $30 \mathrm{~m}$ & 2 & 0 & 0 & 0 & 0 & 0 & 0 & 0 & 0 & 0 & 0 & 0 & 0 & 0 & 0 & 0 \\
\hline 10. Shear Wave Velocity $(\mathrm{m} / \mathrm{sec})$ & 4 & 3 & 3 & 4 & 3 & 3 & 3 & 3 & 3 & 3 & 2 & 3 & 4 & 3 & 3 & 3 \\
\hline 11. Decrease in Shear Wave Velocity $(\mathrm{m} / \mathrm{sec})$ & 2 & 3 & 3 & 2 & 4 & 4 & 2 & 4 & 4 & 4 & 1 & 1 & 1 & 1 & 1 & 1 \\
\hline 12. Bedrock Orientation & 3 & 1 & 1 & 1 & 1 & 1 & 1 & 1 & 1 & 1 & 1 & 1 & 1 & 1 & 1 & 1 \\
\hline 13. Depth to Groundwater (m) & 3 & 1 & 1 & 1 & 1 & 1 & 1 & 1 & 1 & 1 & 1 & 1 & 1 & 1 & 1 & 1 \\
\hline 14. Groundwater Pumping History & 2 & 3 & 3 & 3 & 3 & 3 & 3 & 3 & 3 & 3 & 3 & 3 & 3 & 3 & 3 & 3 \\
\hline 15. Groundwater Flow in Voids & 2 & 2 & 2 & 2 & 2 & 2 & 2 & 2 & 2 & 4 & 2 & 2 & 2 & 2 & 2 & 2 \\
\hline 16. Pipe Leak, within $30 \mathrm{~m}$ & 3 & 0 & 0 & 0 & 0 & 0 & 0 & 0 & 0 & 0 & 0 & 0 & 0 & 0 & 0 & 0 \\
\hline 17. Process Water Discharge, within $30 \mathrm{~m}$ & 3 & 0 & 0 & 0 & 0 & 0 & 0 & 0 & 0 & 0 & 0 & 0 & 0 & 0 & 0 & 0 \\
\hline 18. Storm water Ponding, within $30 \mathrm{~m}$ & 2 & 3 & 3 & 3 & 3 & 3 & 3 & 3 & 3 & 3 & 3 & 3 & 3 & 3 & 3 & 3 \\
\hline 19. Buried Structures, within $30 \mathrm{~m}$ & 2 & 1 & 1 & 1 & 1 & 1 & 1 & 1 & 1 & 1 & 1 & 1 & 1 & 2 & 2 & 2 \\
\hline 20. Soil Disturbance, within $30 \mathrm{~m}$ & 2 & 0 & 0 & 0 & 0 & 0 & 0 & 0 & 0 & 0 & 0 & 0 & 0 & 0 & 0 & 0 \\
\hline 21. Impervious Surfaces, within $30 \mathrm{~m}$ & 3 & 1 & 1 & 1 & 1 & 1 & 1 & 1 & 1 & 1 & 1 & 1 & 1 & 1 & 1 & 1 \\
\hline \multirow[t]{3}{*}{ 22. Data Coverage } & 2 & 3 & 4 & 3 & 2 & 4 & 4 & 3 & 4 & 3 & 4 & 4 & 3 & 3 & 4 & 4 \\
\hline & Total Risk & 95 & 93 & 95 & 99 & 97 & 91 & 101 & 99 & 107 & 89 & 91 & 91 & 95 & 93 & 93 \\
\hline & Ranking & 5 & 6 & 5 & 3 & 4 & 7 & 2 & 3 & 1 & 8 & 7 & 7 & 5 & 6 & 6 \\
\hline
\end{tabular}

N: North side, M: Middle side, S: South side.

many of the risk factors used, and therefore necessarily estimated the conditions conservatively.

Filling these gaps with information will provide a more realistic risk model, and may emphasize specific areas of greater or lesser risk. Based on the risk model developed, ambiguities in the following risk factors have significant impacts in the potential risk at the site.

o Soil density, gradation, and moisture conditions underlying the structure foundations

o Depth to bedrock

o Presence and depth of partially weathered boulders or disintegrated rock

o True thickness of fill

o Location of abandoned pipes and whether or not they act as conduits for retaining moisture

o The shallow groundwater flow regime within the zone of the soil and rock, and if water from the process water overflow or the storm water basins flows underneath the site

o Long-term movement of the turbine foundations

Although it not feasible or cost effective to collect detailed information on all of the potential risk factors, the following steps are recommended to reduce the 
amount of ambiguity in the risk model and to provide needed information to perform the risk reduction measures.

> Conduct a subsurface exploration plan including test borings with sampling through the fill and soil overburden. Soil samples should be logged by a trained geotechnical engineer and analyzed in the laboratory for classification indices, strength, and erosion potential.

$>$ Continue to collect elevations on the turbine foundations at regular intervals to monitor the foundations movements.

Although the geophysical investigations have been very helpful, multiple changes were conducted on the site in between the first and second round of data collection around the turbines. It is recommended to collect another round of geophysical data at the turbines as was conducted previously to further evaluate trends in the data and eliminate the other potential influences on the data.

2) Supplementary Subsurface Exploration

A supplemental subsurface exploration program was conducted in preparation for developing a remedial design and to help alleviate the soil-related unknowns. The supplementary subsurface exploration served to fill many of the key data gaps, and has significantly aided in evaluating the risk of karst related activity at the site. The borings indicated that the outer portions of the site appear to have fill placed directly on Aeolian (i.e., windblown) sand. Stiff to very stiff fat clay residual soil and disintegrated rock underlie the fill and Aeolian sand down to bedrock. The bedrock was cored and encountered highly to intensely fractured limestone, much like the bedrock underlying the main turbine pump block.

3) General Assessment

The test borings provided detailed soils information and confirmed that the conditions around the remaining portions of the site generally have low risk of soil raveling into open fractures and voids of the underlying bedrock. This is primarily because the soil located in between the ground surface and the bedrock has very high cohesion (i.e., stickiness), is partially cemented, and is very stiff. The soil therefore acts as a bridging agent and a buffer to prevent material from migrating downward into open fractures or voids in the subsurface. For the same reason, this type of soil is not prone to migration due to vibration from the turbines.

\section{Preventive and Mitigation Measures}

With reference to the national and international experience in karst management and planning to minimize the encountered risk of structures placed over karst area (Fisher and Canace, 1989, Destephen \& Warge 1992; Beck et al., 1999; Beck \& Herring 2001; Beck \& Pearson, 1995). Continuous monitoring and preventive measures have been applied comprising of the following:

- Surface run-off water management by creating an impervious boundary at the ground surface via paving and directing surface water runoff from the 
western side of the site to a concrete-lined swale. The swale directs surface water runoff to a storm water management basin located to the west-southwest of the site.

- Modification to the plant surroundings has been performed to improve surface water management.

- The existing water effluent pond liners have been refurbished.

- Pipelines have been day lighted to avoid any leakage risk.

- Further monitoring of existing conditions is implemented such as weekly site reconnaissance visits by plant personnel with the aim to observe and record the development of depressions or cracks in the pavement area around the gas turbines, to observe the exposed faces of the concrete foundation, and to observe the operation and alignment of the gas turbines and piping.

- Horizontal and vertical movement monitoring has been initiated, and a baseline has already been obtained.

- The recommended monitoring frequency should be increased as needed, if distress of the foundations, gas turbines, or ancillary structures is observed, or if a movement trend is observed on the monthly monitoring data.

- Groundwater Risk: The groundwater table is about $200 \mathrm{~m}$ deep underlying the site and has little impact on the near surface conditions with the exception that it has dropped significantly since about 1993, which presents a modest risk to increased karst activity in the region due to loss of support and increased vertical groundwater gradients down to the new groundwater table elevation.

Two types of remediation schemes were studied, namely:

1) Improvement of the in situ soils supporting the gas turbines, and

2) Structural retrofitting of the foundations supporting the existing gas turbines.

Furthermore, the conceptual remediation schemes presented herein may not be implemented until deformations, potential instability or lack of support is evidenced at the existing foundation that limits the operation of the gas turbines.

The in situ ground improvement conceptual remediation schemes range from a comprehensive scheme where the in situ soils and rock beneath the foundation of each gas turbine and ancillary structure will be treated from the bottom of the existing foundation to a depth of about $16 \mathrm{~m}$, to a less comprehensive scheme where just the soils directly beneath the foundations are treated to a depth of about $8 \mathrm{~m}$ (Schnabel Engineering, 2012, 2015).

Zone A, located directly underneath the engineered fill, extends from a depth of about 2 to $4 \mathrm{~m}$ below the existing paved surface to a depth of about $8 \mathrm{~m}$ below the existing paved surface. Zone A consists of soils locally known as Marl, residual Silty Sand, and residual Clayey Sand with disintegrated rock fragments.

Zone B is located underneath Zone A from a depth of about $8 \mathrm{~m}$ to $15 \mathrm{~m}$ below the existing paved surface. Zone B consists of fine-grained highly fractured and weathered limestone, with near vertical fractures and sizeable cavities. Previously a foam grouting trial was performed at the base of this zone and $200 \mathrm{~m}^{3}$ 
of foam grout were injected without a surge of pressure.

Zone $\mathrm{C}$, located underneath Zone $\mathrm{B}$, consists of slightly weathered limestone with cavities. A large cavity at around $16 \mathrm{~m}$ below the existing paved surface was also encountered during the previous foam grouting trial, and treated with about $100 \mathrm{~m}^{3}$ of foam grouting without a pressure surge.

Two potential technologies for the treatment of the soil and rock beneath the gas turbines are the following:

1) Low Mobility Grouting (LMG),

2) Jet Grouting.

\section{Conclusion \& Recommendations}

Based on the gathered data, it comes out with the following conclusions and recommendations to treat the affected Zones (Zones A, B and C):

- Natural setting, field observations and historical records of karst features at the study site and surrounding area proved that Al-Hassah Region is classified as "Karstification Landform" and dominated with different types of karst features which can be grouped from Immature Karsts (Classes kI \& kII) to Mature Karsts (Classes kIII - kV). Due to insufficient information on karst feature observed at the study site (e.g. karst morphology, size \& dimensions, and extension etc.) in additional to its sensitivity, it is preferable to consider the karst at the study site as a mature karst (Classes kIII - kV). Therefore, rigorous ground investigation using combination of investigations was considered and undertaken.

- Risk Assessment of the site using probability analysis approach applied in this study show remarkable results in ranking the risk (from Low Risk to High Risk); estimating and predicting the likelihood of future subsidence that could occur under the facilities.

- The absolute risk of sinkholes developing around and under the main turbine pump block, and the site in general, is low. That is, although risk of karst related sinkholes and subsidence remains at the site due to the fact that it is underlain by carbonate bedrock, developing these features is very unlikely to occur without the driving force of large quantities of water.

- Sinkholes that might occur, given concentrated exposure to large volumes of water, type of sinkholes will be limited lateral extent in accordance with the soil characteristics and sinkholes historically observed in the area.

- Treatment of the soil is not required at the site due to the site conditions and normal levels of risk regarding sinkholes in the region, and would not recommend proceeding with the treatment program under ordinary circumstances especially risks involved with the treatment i.e. low mobility grouting program may outweigh the risk of developing sinkholes.

- Managing water on and around the site is also a significant factor to minimizing risk in all karst terrain. Surface water and infiltrating groundwater head have the potential to open clay-filled fractures in the bedrock and ravel soil into the fractures and voids. 
- Mitigating actions have already been performed at the site to reduce infiltration by paving the ground surface and partially directing surface water to infiltration basins located away from the facility.

- A special emphasis should be given to prevent the potential of water infiltration into the partially desiccated marl and erode the soil into the underlying bedrock fracture and void system by maintaining and avoiding spilling large amounts of water on the ground surface or within unlined storm water management basins.

- Joints between adjacent structures and the asphalt pavement should be sealed, and all abandoned boreholes should be backfilled and sealed to avoid allowing groundwater to enter the subsurface and/or the borings from acting as conduits.

- Two potential for the treatment of the soil and rock beneath the gas turbines have been undertaken successfully.

\section{Conflicts of Interest}

The authors declare no conflicts of interest regarding the publication of this paper.

\section{References}

Al Saafin, A. K., \& Ramos, B. (2019). Detection, Delineation and Mitigation of Underground Cavities Using GPR at Spark Eastern Peripheral Road Project. Al-Khobar: Bridge Foundation in Abqaiq Saudi Arabia.

Al Tokhais, A. S., \& Rausch, R. (2008). The Hydrogeology of Al Hassah Springs. In The 3rd International Conference on Water Resources and Arid Environments and the 1st Arab Water Forum, Riyadh (p. 17).

Al-Husseini, M. I. (2000). Origin of the Arabian Plate Structures: Amar Collision and Najd Rift. GeoArabia, 5, 527-542.

Al-Saafin, A. K. (2007). Natural Hazards in Saudi Arabia. As a Part of the Space Image Atlas of the Kingdom of Saudi Arabia (pp. 62-63). Riyadh: Prince Sultan Research Center for Environment, Water and Desert.

Al-Saafin, A. K., \& Geotechnical \& Geophysical Team Members (2018). Detection of Underground Cavities at Housing Project in Al Hassah Region Using Geotechnical Investigation, GPR and MASW Investigation. Al-Khobar: Report Submitted to SLFE Consulting Office.

Al-Sayari, S. S., \& Zötl, J. G. (1978). Quaternary Period in Saudi Arabia. 1: Sedimentological, Hydrogeological, Hydrochemical, Geomorphological and Climatological Investigations in Central and Eastern Saudi Arabia XI, 335 S., Vienna/New York. Berlin: Springer. https://doi.org/10.1007/978-3-7091-8494-3

Beck, B. F., \& Herring, J. G. (2001). Geotechnical and Environmental Applications of Karst Geology and Hydrology (438 p.). Rotterdam: Balkema Publishers.

Beck, B. F., \& Pearson, F. M. (1995). Karst Geohazards. Engineering and Environmental Problems in Karst Terrain (582 p.). Rotterdam: Balkema.

Beck, B. F., Pettit, A. J., \& Herring, J. G. (1999). Hydrogeology and Engineering Geology of Sinkholes and Karst. Conference Proceedings, Chapter 11, Special Session on Highway Karst. Design, Construction and Repair (478 p.). Rotterdam: Balkema. 
BRGM, Bureau de Recheres Geologiques et Ministeres (1977). Al Hassa Development Project Groundwater Study and Management Programme. Final Unpublished Report, Riyadh: Groundwater Resources Development Department, Ministry of Agriculture and Water.

Brook, G. A., \& Allison, T. L. (1986). Fracture Mapping and Ground Susceptibility Modeling. In Covered Karst Terrain: The Example of Dougherty County, Georgia. Proceedings of Symposium on Land Subsidence (pp. 595-606). IAHS Publication 151, Wallingford, CT: International Association of Hydrological Sciences.

Buttrick, D., \& van Schalkwyk, A. (1998). Hazard and Risk Assessment for Sinkhole Formation on Dolomite Land in South Africa. Environmental Geology, 36, 170-178. https://doi.org/10.1007/s002540050333

Chapman, R. W. (1978). Geology. In S. S. Al-Sayari, \& J. G. Zötl (Eds.), Quaternary Period in Saudi Arabia (pp. 4-18). Wien/New York: Springer.

https://doi.org/10.1007/978-3-7091-8494-3_3

Cvijić, J. (1893) Das Karstphanomen. Versuch einer morphologischen Monographie. Geographischen Abhandlung, Wien V, 3, 218-329.

Davies, J. A., \& Lord, J. A. (1981). The Effects of Cavities in Limestone on the Construction of a High Rise Building in Al Khobar, Saudi Arabia. In Geotechnical Problems in Saudi Arabia (Vol. Ia, 16 p.).

De Jong, R. L., Yazicigil, H., \& Al-Layla, R. I. (1989). Scenario Planning for Water Resources: Saudi Arabian Case Study. Water International, 14, 6-12. https://doi.org/10.1080/02508068908692025

Destephen, R. A., \& Wargo, R. H. (1992). Foundation Design in Karst Terrain. Bulletin of the Association of Engineering Geologists, 29, 165-173. https://doi.org/10.2113/gseegeosci.xxix.2.165

Dhowian, A. W., \& Youssef, A. (1981). Properties and Classification of Arab Rock Formation. In Geotechnical Problems in Saudi Arabia (Vol. Ia, 15 p).

Dreybrodt, W., \& Eisenlohr, L. (2000). Limestone Dissolution Rates in Karst Environments. In A. Klimchouk, D. C. Ford, A. N. Palmer, \& W. Dreybrodt (Eds.), Speleogenesis: Evolution of Karst Aquifers (pp. 136-148). Huntsville, AL: National Speleological Society.

Edgell, H. S. (1987). Geological Report on the Upper Tertiary Strata of the Eastern Province with Reference to Their Hydrogeology (24 p).

Edgell, H. S. (1990). Geological Framework of Saudi Arabian Groundwater Resources. Journal of King Abdulaziz University, Earth Sciences, 3, 267-286. https://doi.org/10.4197/Ear.3-1.23

Edgell, H. S. (1993). Karst and Water Resources in the Hyperarid Areas of Northeastern Saudi Arabia. In Proceedings of Articles of International Karst Symposium (Vol. I, pp. 309-326).

El-Mahmoudi, A. S., Al-Barrak, K. M., \& Massoud, M. A. (2011). 2-D Electrical Tomography for Mapping of Aquifers at the New Campus of King Faisl University, Al Hassa, KSA. International Journal of Water Resources and Arid Environments, 1, 397-410.

El-Ruwaih, I. A., \& Khandker, A. (1981). On the Geotechnical Conditions of Riyadh Area, Saudi Arabia. In Geotechnical Problems in Saudi Arabia (Vol. Ia, 25 p).

Fischer, J. A., \& Canace, R. (1989). Foundation Engineering Construction in Karst Terrane. In Foundation Engineering. Current Principles and Practices (pp. 29-42). Evanston, IL: ASCE.

Fookes, P. G., \& Hawkins, A. B. (1988). Limestone Weathering: Its Engineering Signific- 
ance and a Proposed Classification Scheme. Quarterly Journal of Engineering Geology, 21, 7-31. https://doi.org/10.1144/GSL.QJEG.1988.021.01.02

Ford, D. C., \& Williams, P. F. (1989). Karst Geomorphology and Hydrology (601 p.). London: Unwin Hyman. https://doi.org/10.1007/978-94-011-7778-8

Galve, J. P., Bonachea, J., Remondo, J. et al. (2008). Development and Validation of Sinkhole Susceptibility Models in Mantled Karst Settings. A Case Study from the Ebro Valley Evaporite Karst (NE Spain). Engineering Geology, 99, 185-197. https://doi.org/10.1016/j.enggeo.2007.11.011

Galve, J. P., Gutiérrez, F., Lucha, P., Guerrero, J., Bonachea, J., Remondo, J., \& Cendrero, A. (2009). Probabilistic Sinkhole Modeling for Hazard Assessment. Earth Surface Process and Landforms, 34, 437-452. https://doi.org/10.1002/esp.1753

Gao, Y., \& Alexander, E. C. (2003). A Mathematical Model for a Map of Relative Sinkhole Risk in Fillmore County, Minnesota. In B. F. Beck (Ed.), Sinkholes and the Engineering and Environmental Impacts of Karst (pp. 439-449). Geotechnical Special Publication No. 122, Reston, VA: American Society of Civil Engineers. https://doi.org/10.1061/40698(2003)39

Grosch, J. J., Touma, F. T., \& Richards, D. P. (1987). Solution Cavities in the Limestone of Eastern Saudi Arabia: Karst Hydrogeology, Engineering and Environmental Applications. In Multidisciplinary Conference on Sinkholes and the Environmental Impacts of Karst (pp. 73-78).

Holm, D. A. (1960). Desert Geomorphology in the Arabian Peninsula. Science, 132, 1369-1379. https://doi.org/10.1126/science.132.3437.1369

Holtz, H., Maurin, V., \& Zotl, J. G. (1978). Geologic History of the Al Hasa Area since Pliocene. In S. S. Al-Sayari, \& J. G. Zotl (Eds.), Quaternary Period in Saudi Arabia (pp. 58-77). Berlin: Springer-Verlag.

Hussain, M., Al-Khalifah, F., \& Khandaker, N. I. (2006). The Jabal Al Qarah Caves of the Hofuf Area, Northeastern Saudi Arabia: A Geological Investigation. Journal of Cave and Karst Studies, 68, 12-21.

Italconsult, T. (1969). Water and Agricultural Development Studies for Area in Eastern Province, Snurli Arabia. Riyadh: Ministry of Agriculture ANCL Water.

Jado, A. R., \& Johnson, D. H. (1983). Solution Caverns in the Dammam Dome, Dhahran, Saudi Arabia. Arabian Journal for Science and Engineering, 8, 69-73.

Jiang, L. M., Jiang, X., \& Yu, L. (2001). New Advances of Karst Collapse Research in China. In B. F. Beck, \& J. G. Herring (Eds.), Geotechnical and Environmental Applications of Karst Geology and Hydrology (pp. 145-151).

Kannan, R. C. (1999). Designing Foundations around Sinkholes. Engineering Geology, 52, 75-82. https://doi.org/10.1016/S0013-7952(98)00057-X

Kaufmann, O., \& Quinif, Y. (2002). Geohazard Map of Cover-Collapse Sinkholes in the Tournaisis Area, Southern Belgium. Engineering Geology, 65, 117-124. https://doi.org/10.1016/S0013-7952(01)00118-1

Milanovic, P. T. (2004). Water Resources Engineering in Karst (312 p.). Boca Raton, FL: CRC Press. https://doi.org/10.1201/9780203499443

Naimi, A. I. (1965). The Groundwater of Northeastern Sandi Arabia. In Firth Arab Petroleum Congress (pp. 16-23). Cairo: Secretariat General of the Arab League.

Nejem, J. K. (1994). Numerical Simulation of Groundwater Depletion in Al-Hasa Area. M.Sc. Thesis, Dhahran: KFUM.

Peters, W. D., Pint, J. J., \& Kremla, N. (1990). Karst Landforms in the Kingdom of Saudi Arabia. The NSS Bulletin, 52, 21-32. 
Pint, J. (2003). The Desert Caves of Saudi Arabia (120 p.). London: Stacey International.

Pint, J., \& Bjurström, L. (2000). Saudi Arabia's Desert Caves. Aramco World, 51, 26-38.

Powers, R. W. et al. (1966). Geology of the Arabian Peninsula; Sedimentary Geology of Saudi Arabia (pp. 1-127). https://doi.org/10.3133/pp560D

Rasheeduddin, M. (1988). Numerical Modeling of Alat, Khobar, and Umm Er Radhuma Aquifer System in Eastern Saudi Arabia. M.S. Thesis, Dhahran: KFUPM.

Reith, C. M., Cadden, A. W., \& Naples, C. J. (1999). Engineers Challenged by Mother Nature's Twist of Geology, In B. F. Beck, A. J. Pettit, \& J. G. Herring (Eds.), Hydrology and Engineering Geology of Sinkholes and Karst (pp. 149-155). Rotterdam: Balkema.

RI-KFUPM (1984-1999). Karstification Study in Ma'aglah Area. Cooperative Program with the Austrian Academy, Vienna and Karlsruhe University, West Germany.

Sabtan, A., Fayed, L. A., \& Khiymah, H. A. (2013). Evaluation of the Sinkholes Hazard at Al Issawiah S. of Qurayat, Jouf Region of Saudi Arabia. Al-Azhar Bulletin of Science, 24, 1-16. https://doi.org/10.21608/absb.2013.6572

Saner, S., Al-Hinai, K., \& Perincek, D. (2005). Surface Expressions of the Ghawar Structure, Saudi Arabia. Marine and Petroleum Geology, 22, 657-670.

https://doi.org/10.1016/j.marpetgeo.2004.12.006

Schnabel Engineering (2012). Geotechnical Report, Cavities Study and Remedial Foundation Support Contingency Plan, Uthmaniyah Water Supply Plant, Al-Hasa, Saudi Arabia, ASC Contract No. 6500010120. Schnabel Reference 12612056, November 14, 2012.

Schnabel Engineering (2015). Supplemental Subsurface Exploration Data Report, UWSP Turbine Foundation LMG Remediation Design and Construction Services, Uthmaniyah Water Supply Plant (UWSP), Al Ahsa, Saudi Arabia, ASC Contract No. 6500013642. Schnabel Reference 12612056.01, November 13, 2015.

SGS, Cavity Unit (2000-2016). Allocation and Mapping the Underground Cavities Distributed in the Entire Saudi Arabia. Jeddah: Saudi Geological Survey (SGS).

Shehata, W. M., Bader, T., \& Harari, Z. Y. (1990). Principal Geological Hazards along the Arabian Gulf Coast. Journal of King Abdulaziz University, Earth Sciences, 3, 289-302. https://doi.org/10.4197/Ear.3-1.24

Shehata, W., Roobol, J. M., Stewart, I., Khiyami, H., Al Khammash, A., Sayed, S., Tarabolsi, Y., \& Al Ahmadi, K. (2007). Evaluation of a Subsidence Hazard in the Al Khafji Area. Confidential Report Saudi Geological Survey.

Siegel, T. C., Belgeri, J. J., \& Terry, M. W. (1999). Compaction Grouting versus Cap Grouting for Sinkhole Remediation in East Tennessee. In Hydrology and Engineering Geology of Sinkholes and Karst (pp. 157-163). Balkema: Rotterdam.

Sum, C. W., Othman, J., \& Loganathan, P. (1996). Geotechnical Problems in Limestone Terrain with Emphasis on Cavities and Sinkholes. In Seminar Geologi dan Sekitarn, UKM, Puri Pujangga (pp. 102-117). Bangi: Universiti Teknologi Petronas.

TC32-Technical Committee 32 (Engineering Practice of Risk Assessment and Management) of the International Society of Soil Mechanics and Geotechnical Engineering (ISSMGE) (2004). Risk Assessment-Glossary of Terms.

Thomas, B., \& Roth, M. J. S. (1999). Evaluation of Site Characterization Methods for Sinkholes in Pennsylvania and New Jersey. Engineering Geology, 52, 147-152. https://doi.org/10.1016/S0013-7952(98)00068-4

Tolmachev, V., \& Leonenko, M. (2011). Experience in Collapse Risk Assessment of Building on Covered Karst Landscapes in Russia. In Karst Management Book (pp. 75-103). Dordrecht: Springer. https://doi.org/10.1007/978-94-007-1207-2_4

Tolmachev, V., Maximova, O., \& Mamonova, T. (2005). Some New Approaches to As- 
sessment of Collapse Risks in Covered Karsts. In B. F. Beck (Ed.), Sinkholes and the Engineering and Environmental Impacts of Karst (pp. 649-656). https://doi.org/10.1061/40796(177)8

Touma, F. T., \& Bellerjeau, W. R. (1981). Experience with Foundations of Structures on Rock in Saudi Arabia. In Geotechnical Problems in Saudi Arabia (Vol. Ia, 49 p).

UN-ISDR (2004). Terminology of Disaster Risk Reduction. Geneva: United Nations International Strategy for Disaster Reduction.

van Beynen, P. E. (2011). Karst Management (489 p). Dordrecht: Springer.

Vaslet, D., Al Muallem, M. S., Madah, S. S., \& Shorbaji, H. (1988). Preliminary Technical Investigation of a Crevasse Opened at Al Kharj End of February 1988 (10 p). Ministry of Petroleum and Minerals Report, BRGM-JED-IR-88-1.

Villard, P., Gourc, J. P., \& Giraud, H. (2000). A Geosynthetic Reinforcement Solution to Prevent the Formation of Localized Sinkholes. Canadian Geotechnical Journal, 37, 987999. https://doi.org/10.1139/t00-002

Waltham, A. C., \& Fookes, P. G. (2003). Engineering Classification of Karst Ground Conditions. Quarterly Journal of Engineering Geology \& Hydrogeology, 36, 101-118. https://doi.org/10.1144/1470-9236/2002-33

White, W. B. (1988). Geomorphology and Hydrology of Karst Terrains. New York: Oxford University Press.

Williams, R. O. (1974). Meteorological and Oceanographic Data. Dhahran: Arabian Oil Company.

Xeidakis, G. S., Torok, A., Skias, S., \& Kleb, B. (2004). Engineering Geological Problems Associated with Karst Terrains: Investigation, Monitoring and Mitigation and Design of Engineering Structures on Karst Terrain. Bulletin of the Geological Society of Greece 36, 1932-1941. https://doi.org/10.12681/bgsg.16679

Yazicigil, H., Al-Layla, R. I., \& De Jong, R. I. (1986). Numerical Modeling of the Dammam Aquifer in Eastern Saudi Arabia. The Arabian Journal for Science and Engineering, 11, 349-362.

Yilmaz, I. (2007). GIS Based Susceptibility Mapping of Karst Depressions in Gypsum: A Case Study from Sivas Basin (Turkey). Engineering Geology, 90, 89-103. https://doi.org/10.1016/j.enggeo.2006.12.004

Youssef, A. M., Al-Harbi, H. M., Zabramwi, Y. A., \& El-Haddad, B. A. (2016). HumanInduced Geo-Hazards in the Kingdom of Saudi Arabia (pp. 37-61). London: InTech. https://doi.org/10.5772/66306

Zabramawi, Y. A., Khiyami, H., Youssef, A. M., Sabtan, A. A., Al-Harthi, S. G., Memash, A., Al-Sharef, A., \& Al-Ahmadi, K. Z. (2009). Karst Investigation and Analysis in an Nu'ayriyah Area, Kingdom of Saudi Arabia. Saudi Geological Survey Technical Report SGS-TR-2009-6.

Zhou, W., \& Beck, B. F. (2011). Engineering Issues on Karst. In Karst Management (pp. 9-46). Dordrecht: Springer. https://doi.org/10.1007/978-94-007-1207-2_2

Zhou, W., Beck, B. F., \& Adams, A. (2003). Application of Matrix Analysis in Delineating Sinkhole Risk Areas along Highway (I-70 near Frederick, Maryland). Environmental Geology, 44, 834-842. https://doi.org/10.1007/s00254-003-0828-8

Ziegler, M. A. (2001). Late Permian to Holocene Paleofacies Evolution of the Arabian Plate and Its Hydrocarbon Occurrences. GeoArabia, 6, 445-504. 